\title{
Performance analysis of horizontal ground source heat pump for building cooling in arid Saharan climate: thermal-economic modeling and optimization on TRNSYS
}

\author{
Sabrin Korichi ${ }^{1, *}$, Bachir Bouchekima ${ }^{1}$, Nabiha Naili ${ }^{2}$, and Messaouda Azzouzi ${ }^{3}$ \\ ${ }^{1}$ Laboratory of New and Renewable Energies in Arid and Saharan Areas-LENREZA, University of Kasdi Merbah-Ouargla \\ Po Box 511 30000, Ouargla. Algeria \\ ${ }^{2}$ Laboratory of Thermal Processes, Research and Technology Center of Energy, Hammam Lif, B.P. 95, 2050 Tunis, Tunisia \\ (CRTEn) \\ ${ }^{3}$ Department of Electrical Engineering, Faculty of Science and Technology, University Ziane Achour of Djelfa, Djelfa 17000, \\ Algeria
}

Received: 8 November 2020 / Received in final form: 8 December 2020 / Accepted: 8 December 2020

\begin{abstract}
This paper presents a feasibility and performance study of ground source heat pump (GSHP) coupled with horizontal ground heat exchanger (HGHX) used for cooling residential unit equipped with radiant floor system (RFs) under the meteorological conditions of Saharan environment in Ouargla, city located in Southeast Algeria. A dynamic simulation system is developed using TRNSYS software for modeling the performance of the GSHP system. To verify the reliability of GSHP including HGHX system programs, the modeling procedure was validated against experimental data from a horizontal ground source heat pump system (HGSHPs) installed at the Research and Technology Center of Energy (CRTEn), Tunisia, and a good agreement was obtained. Then, to obtain an acceptable balance between system efficiency and total cost of HGSHPs an economic analysis was carried out to determine the optimum design parameters of the HGHX. The simulation results obtained from this study indicated that the HGSHPs could effectively solve cooling problem and reduce traditional energy consumption in the Saharan areas; it is possible to lower the mean indoor air temperature below $27^{\circ} \mathrm{C}$ and raise the average relative humidity to reach $73.97 \%$. By concentrating principally on the thermal-economic optimization, the optimized COP of the GSHP that combines the reliability and economy of cooling in long term was found to be 3.89 .
\end{abstract}

\section{Introduction}

The energy consumption in urban buildings has gained an increasing demand recently due to the high comfort standards [1]. This energy reaches about $40 \%$ of the world's energy use, for example, in Algeria, the residential sector is the largest consumer of energy, accounting about $43 \%$ of the total national energy consumption [2]. This value will increase to reach $179.78 \mathrm{TWh}$ in 2040 with the increasing of population and because of urbanization and improvement of the living standard [2]. Indeed, these values indicate that the residential sector represents the largest source of greenhouse gas emissions (GHG) and ecological problems in the world.

\footnotetext{
* e-mail: sabrinskemr@gmail.com
}

In recent years, global warming has become a major threat to the environment, especially in arid and semi-arid areas where the desert regions in southern Algeria recorded a significant increase in temperatures that exceeded the normal rate, which constituted a burden on conventional air conditioners to provide the cooling needs for the buildings during the summer. Therefore, it is necessary to highlight the use of new technologies based on renewable energies, which still represents only $0.1 \%$ of Algerian energy consumption [3]. The renewable energy that appears to be very well adapted in the building sector is the geothermal energy; it represents the solution for reducing the large energy consumption and environmental problems of the building sector.

The shallow geothermal energy is a clean, sustainable and low carbon solution for the heating and cooling of buildings by pumping heat from or to the shallow subsurface to provide the thermal loads. Compared with 
other renewable sources, the shallow geothermal energy has important advantage, it can be used everywhere in the world especially in residential sector areas where the quantity of exploitable geothermal energy stored in the shallow subsurface is greater than its annual requirements for cooling and heating.

In the last decades, shallow geothermal systems such as ground source heat pump systems have been increasingly applied to heating and cooling residential buildings and infrastructure. Among the different types of GSHPs, the closed ground source heat pump system (GCHP) is one of the best configurations in terms of practicability and independent installation. It consists of heat exchanger loops that utilize the heat conduction mechanism of the ground to reject or extract heat.

The ground loop pipes or the ground heat exchangers, which are placed horizontally or standing vertically in ground, have the largest portion of investment cost in ground source heat pumps installation [4]. Compared with vertical GHXs, the horizontal GHXs require longer pipe length and ground surface area but they are typically less expensive due to the lower cost of drilling and refilling. However, the investment price remains relatively high compared to the air conditioning system, Therefore, the process of improvement of the system must be carried out during the sizing of GHX in order to obtain the most costeffective design parameters and thus avoiding the significant financial losses [4-6].

Over the last two decades, several studies have shown the importance of conducting a pre-design analysis to determine the influence of well properties on ground source heat pump performance and installation costs, modeling a software program based on a model of ground heat exchanger and evaluating the optimum technical characteristics of the GSHP. Sanaye et al. [7] presented a modeling and optimizing processes for a GSHP coupled with HGHX by defining the total annual cost (total of investment and operation costs) as an objective function using Nelder-Mead and Genetic algorithm techniques to estimate the optimum design parameters of the system as well as the configuration of HGHX. Their study indicated that the system parameters (saturated temperature condenser and evaporator, inlet and outlet temperatures of the water source and GHX nominal pipe diameter) have a significant effect on ground coupled heat pump performance and the total annual cost of the system. Therefore, it is necessary to pre-investigate the exploitation of closed geothermal systems before any field application in given climatic conditions in order to obtain optimum system parameters that ensure high efficiency and lower cost. Kayaci et al. [8] studied the energy and economic analysis of HGHX used for cooling and heating an office with a total conditioned space of about $200 \mathrm{~m}^{2}$ in Turkey. The effect of all geometric properties of the designed horizontal GHE as well as the effects of the rate of increase in electricity prices was investigated by defining a reference function (total cost) as an optimization parameter. In their simulation study, found that the number of parallel pipe, burial depth, pipe spacing, tube diameter and pipe length have a major impact on the performance of the GSHP and the reference function because it affects the excavation and labor costs and the amounts of heat extracted from soil or transferred to soil, simultaneously. Thus, they concluded that it is feasible to examine all parts of GSHP system in the predesign analysis to obtain the optimal design parameters that ensure a balance between efficiency and costs. Suggested values for all of these engineering properties are recommended.

Inalli et al. [9] the effects of various system parameters such as the buried depth of earth coupled heat exchanger, the mass flow rate of the water antifreeze solution and the sewer water on the performance of ground source heat pumps were examined based on experimental analysis conducted in Turkey. It was found that the poor design of the GSHP system caused lower performance factors when compared their results to other heat pumps operating under the same design values. They concluded that it is necessary to conduct a pre-design analysis to determine optimal system parameters that will ensure minimum energy consumption and favorable costs with the help of GSHP simulation models. Reliable numerical models and methods were shown in various studies [10-12].

The properties of the soil, actual loads of buildings and meteorological factors play a significant role in the design of the geothermal heat exchangers. In recent years, many studies dealing with the influence of soil thermo-physical characteristics on ground source heat pump performance have been published $[13,14]$. Most researchers have found that the undisturbed soil temperature and ground resistance, which vary with time and space strongly affects the amount of geothermal energy that can be transferred to or extracted from the ground. This leads to significant differences in GSHP thermal performance from one region to another which changes the design criteria for the ground heat exchangers, especially for the horizontal ones, since they are the closest to the ground surface and the most affected by external factors. Geological and climate conditions can also strongly influence the GSHP operation and the total cost of the GHX system.

In this context, the main aim of this study was to preinvestigate the exploitation of horizontal ground source heat pump systems for cooling in arid Saharan environment. A TRNSYS model of HGSHPs equipped with RFs is proposed to provide the cooling for residential building of about $95 \mathrm{~m}^{2}$ area located in Ouargla, South-East of Algeria. The model was validated using experimental data collected from a HGSHPs conducted in the Research and Technology Center of Energy at Borj Cédria, northern Tunisia. For optimal system design, a thermal-economic optimization was carried out to estimate the optimum HGHX design parameters for the case study region. The effect of the pipe length, burial depth, pipe diameter and mass flow rate on the thermal performance and the system total cost were investigated. Then to ensure the reliability of the optimization results, the simulation inlet and outlet temperatures of the HGHX were calibrated using ASHRAE guideline constraints.

\section{The test region}

As a future working project, the optimized HGSHPs is mainly designed to be installed and tested in hot-dry and 
Table 1. The min max average monthly variation of outdoor temperatures and the average monthly variation of relative humidity and wind speed in the year 2019.

\begin{tabular}{llllll}
\hline Months & $\begin{array}{l}\text { Minimum temperature } \\
\left({ }^{\circ} \mathrm{C}\right)\end{array}$ & $\begin{array}{l}\text { Maximum temperature } \\
\left({ }^{\circ} \mathrm{C}\right)\end{array}$ & $\begin{array}{l}\text { Average temperature } \\
\left({ }^{\circ} \mathrm{C}\right)\end{array}$ & $\begin{array}{l}\text { Average relative } \\
\text { humidity }(\%)\end{array}$ & $\begin{array}{l}\text { Average wind } \\
\text { speed }(\mathrm{m} / \mathrm{s})\end{array}$ \\
\hline Jan & 4 & 18.4 & 10.8 & 40.8 & 2.9 \\
Feb & 4.9 & 19.2 & 12 & 37.8 & 3.8 \\
Mar & 9.2 & 24.2 & 16.9 & 33.5 & 4.0 \\
Apr & 15.5 & 30.2 & 23.2 & 25.9 & 4.1 \\
May & 19 & 33.3 & 26.7 & 25 & 4.5 \\
Jun & 26.6 & 42.6 & 35.3 & 13.9 & 4.9 \\
Jul & 28.8 & 44.5 & 37.4 & 13.8 & 3.6 \\
Aug & 29.7 & 43.5 & 36.9 & 17.8 & 3.7 \\
Sep & 24 & 39.1 & 31.8 & 27.5 & 3.6 \\
Oct & 24.2 & 31 & 17.2 & 35.8 & 2.9 \\
Nov & 9.3 & 23.3 & 16.2 & 37.3 & 3.1 \\
Dec & 7.1 & 21.1 & 13.8 & 46.7 & 2.9 \\
\hline
\end{tabular}

desert environments. It has been proposed to meet the thermal comfort requirements of a house model under climatic conditions of Ouargla city, Algeria. The city of Ouargla is situated in north-eastern of the Algerian Sahara, it is located at $164 \mathrm{~m}$ altitude, $31^{\circ} 57^{\prime} \mathrm{N}$ latitude and $5^{\circ} 21^{\prime} \mathrm{E}$ longitude and covers a total area of about $163.233 \mathrm{~km}^{2}$. It has a dry desert climate, which is characterised by mild winters and very hot-dry summers. The average, minimum and maximum monthly variation of temperatures, including the average monthly variation of the wind speed and relative humidity measured with the meteorological weather station of Ouargla during the year 2019 were displayed in Table 1.

The study region of this work is one of the main geothermal areas in Algeria, as illustrated in Figure 1. It is characterized by a mean gradient of $21^{\circ} \mathrm{C} / \mathrm{km}$, which corresponds very high geothermal heat flow values (ranging between 80 and $100 \mathrm{~mW} / \mathrm{m}^{2}$ ) [15].

The hydraulic drilling that crosses the Saharan territory indicates that this area is mainly covered with Tertiary and Quaternary materials [16], which are characterized by a sandy limestone majority in the surface layers of lithological classifications.

\section{Basics of the design}

\subsection{Thermal modeling analysis}

Using the first law of thermodynamics, the heat absorbed from the building $Q_{b}$ and the heat transferred to the ground $Q_{g}$ can be computed from the following equations:

$$
\begin{gathered}
Q_{b}=\dot{m}_{w-R F} C_{p-H_{2} O}\left(T_{i n-R F}-T_{\text {out }-R F}\right) \\
Q_{g}=\dot{m}_{w-G H X} C_{p-H_{2} O}\left(T_{\text {in-GHX }}-T_{\text {out }-G H X}\right)
\end{gathered}
$$

The heat transfer rate from tank storage to refrigerant via the evaporator is:

$$
Q_{E v p}=\dot{m}_{w-E v p} C_{p-H_{2} O}\left(T_{i n-E v p}-T_{o u t-E v p}\right)
$$

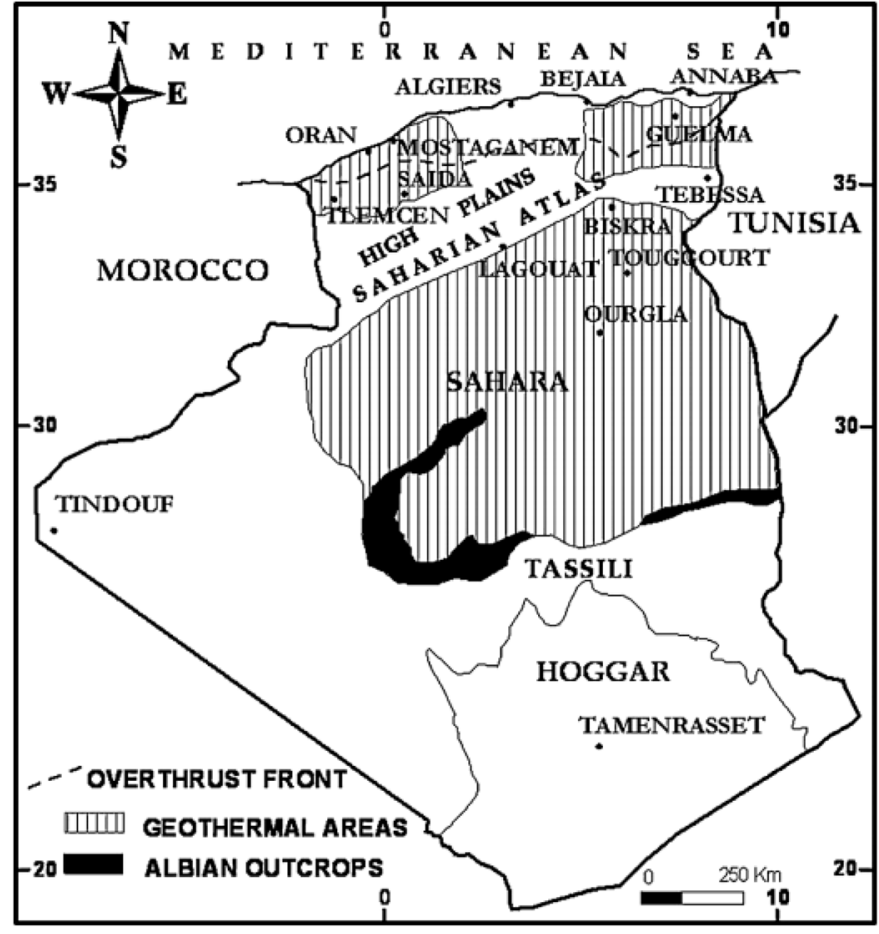

Fig. 1. Main Algerian geothermal areas [15].

The heat transfer rate from condenser to ground loop is:

$$
Q_{C o n}=\dot{m}_{w-C o n} C_{p-H_{2} O}\left(T_{\text {out }-\mathrm{Con}}-T_{\text {in-Con }}\right)
$$

The compressor power is expressible as:

$$
\dot{W}_{C o m}=Q_{C o n}-Q_{E v p}
$$

The heat pump coefficient of performance (COP) estimated by the ratio between the heat absorbed from 
building and the compressor power input:

$$
C O P=\frac{Q_{E v p}}{\dot{W}_{\text {Comp }}}
$$

The seasonal energy efficiency ratio (SEER) can be calculated from:

$$
S E E R=\frac{(1.12-\sqrt{(1.2544-0.08 E E R)})}{0.04}
$$

Where EER is the energy efficiency ratio.

\subsection{Economic performance analysis}

Because of the high investment cost of the ground heat exchanger installation and the large cost of long-term electricity consumption, the objective of this part was to minimize the initial and operation costs of HGSHPs for the building cooling capacity in which the thermal performance of the GSHPs was considered (i.e.- COP). Thus, an economic analysis was performed by defining an objective function to obtain the optimized values of GHX parameters design.

\subsubsection{Objective function}

An objective function, $\mathrm{OF}(\$ / \mathrm{kW})$, was defined by dividing the total cost into the total annual cooling loads:

$$
O F=\frac{T A C}{Q_{c} \times T_{c}}
$$

where $Q_{c}$ and $T_{c}$ are the cooling load and annual cooling operation hours per year respectively, the TAC is the total annual cost which contains the investment and the electricity costs, was defined as:

$$
T A C=C R F\left(C_{i n v}+C_{\text {elec }}\right)
$$

Then

where CRF, is the capital recovery factor, expressed as:

$$
C R F=\frac{i}{1-(i+1)^{-n}}
$$

$i$ and $n$ are interest rate and number of operation years, respectively.

Thus, the objective function can be reformulated by following equation:

$$
O F=O F_{i n v}+O F_{\text {elec }}
$$

Where:

$$
\begin{gathered}
O F_{i n v}=\frac{C R F \times C_{i n v}}{Q_{c} \times T_{c}} \\
O F_{\text {elec }}=\frac{C R F \times C_{\text {elec }}}{Q_{c} \times T_{c}}
\end{gathered}
$$

\subsubsection{The annual cost of the power consumption}

The annual electricity consumption of GSHP systems includes the annual energy consumption of compressor and circulating pump:

$$
E=E_{\text {pump }}+E_{\text {comp }}
$$

The annual electricity consumption of the compressor, $E_{\text {comp }}(\mathrm{kWh})$, can be determined as:

$$
E_{\text {comp }}=T_{c} W_{\text {comp }}
$$

The annual electricity consumption of the circulating pump, $E_{\text {pump }}(\mathrm{kWh})$, can be determined as:

$$
E_{\text {pump }}=\tau_{c} \frac{\dot{m}_{w} H_{\text {pump }}}{\rho_{w} \eta_{\text {pump }}}
$$

where $\tau_{c}(\mathrm{~h})$ is the total running hours in the cooling period. $H_{\text {pump }}$ is the total pumping head in the HGHX $\left(\Delta p_{G H X}\right)$ and heat pump $\left(\Delta p_{G H P}\right)$.

Thus, the total annual electricity consumption, $C_{\text {elec }}$ $(\$)$, is obtained as follows:

$$
C_{\text {elec }}=\left(E_{\text {pump }}+E_{\text {comp }}\right) E_{\text {tariff }}
$$

where $E_{\text {tariff }}(\$ / \mathrm{kWh})$, is the price of electricity for each $\mathrm{kWh}$, which can be obtained from Sonelgaz [17].

And finally, the total cost of electricity consumption for 10-year period is obtained as follows:

$$
C_{\text {elec }}=C_{\text {elec }, 1}+\sum_{n=2}^{n=10} C_{\text {elect }, n} e
$$

where $e$ is the increases in electricity prices.

\subsubsection{The annual capital cost}

For the total investment cost of GSHP system including the GHX, $C_{i n v}(\$)$ a reference function was defined as:

$$
C_{i n v}=C_{\text {Pipe }}+C_{\text {earthwork }}+C_{\text {heatpump }}+C_{\text {pump }}
$$

For the cost of pipes,earthwork, pump, heat pump unit, the following cost functions were applied [18]:

$$
\begin{gathered}
C_{\text {Pipe }}=c_{\text {Pipe }}(N P T) L_{G H X} \\
C_{\text {earthwork }}=a_{1}(N P T) L_{G H X} Z \\
C_{\text {heatpump }}=a_{2} Q_{\text {heatpump }}^{a 3} \\
C_{\text {pump }}=a_{4} W_{\text {pump }}^{a 5}
\end{gathered}
$$

where:

$c_{\text {Pipe }}$ is the regional cost of polyethylene pipe per meter which depending on the diameter of pipes, (Tab. 2) NPT is the number of parallel pipe and $L_{G H X}$ is the total required 
Table 2. Polyethylene pipe (type SDR11) data [19].

\begin{tabular}{llll}
\hline $\begin{array}{l}\text { Inner diameter } \\
(\mathrm{mm})\end{array}$ & $\begin{array}{l}\text { Outer diameter } \\
(\mathrm{mm})\end{array}$ & $\begin{array}{l}\text { Thickness } \\
(\mathrm{mm})\end{array}$ & $\begin{array}{l}\text { Price } \\
(\$ / \mathrm{m})\end{array}$ \\
\hline 18 & 20 & 2 & 0.81 \\
22.7 & 25 & 2.3 & 1.17 \\
29 & 32 & 3 & 1.79 \\
36.3 & 40 & 3.7 & 2.66 \\
\hline
\end{tabular}

length of the HGHX. Z is the depth of the ground. $a_{1}$ is the regional price of the drilling and refilling $\left(\$ / \mathrm{m}^{2}\right) \cdot a_{2}-a_{5}$ are constant coefficients which were obtained based on the manufacturer's data according to the given required cooling capacity and the regional price of the equipments. (Tab. 2)

\section{Model development and validation}

As stated in Section 1, the model in this work focuses on pre-investigating the exploitation of HGSHPs for cooling a residential unit in a dry desert climate. A simulation model of the geothermal system has been proposed consisting of water-to-water heat pump, a water tank with immersed heat exchangers, horizontal ground heat exchanger, water circulation pumps and the RF system.

A novel method based on multi-year energy and economic analysis has been developed in order to achieve the two main goals of the model: reducing the total investment and operation costs as much as possible while ensuring a good system efficiency. The energy performance of GSHP was evaluated with a developed TRNSYS model. Then, the numerical outputs were used in the economic performance analysis to obtain the moste cost-effective design parameters of the HGHX. Because of the massive computations in the optimization process, a MATLAB code was used to evaluate the objective function based on equation (8).

The description of the HGSHP dynamic simulation model and its validation, which was performed by comparing the simulation results with measured data obtained by experimental device will be presented in the following sections, while the schematic diagram containing the algorithm procedure is shown in Figure 2.

\subsection{TRNSYS model description}

The entire model of the HGSHPs was simulated in the TRNSYS 16 simulation environment. Figure 3 shows the simulation system developed for the cooling of the building exemple. The overall model is composed of four important sub-models: the building, the ground heat pump, the data acquisition (DAQ) system and the horizontal ground heat exchanger. This model includes the main components for the installation which can be provided from the TRNSYS library (standard models). It is summarized in Table 3.
The simulation time step was set at $5 \mathrm{~min}$ in order to capture any thermal behavior of the system during the simulation periods. The set point temperature for cooling is $25.5^{\circ} \mathrm{C}$ when the compressor switch on and $26.5^{\circ} \mathrm{C}$ when the compressor switch off and the set point temperature inside the water storage tank was set as $6^{\circ} \mathrm{C}$ when the compressor switch on and $13^{\circ} \mathrm{C}$ when the compressor switch off.

\subsubsection{Building thermal model description}

A one-story residential house with a floor area of $95 \mathrm{~m}^{2}$ and an internal height of $3 \mathrm{~m}$ was created in Room Arranger for the simulation performance analysis in the TRNSYS environment. The model of the building with northern orientation was divided into six thermal zones corresponding to the living requirements (three bedrooms, a kitchen, a living room and one toilet).

The following suggestions are also included in the house model and load characteristics topics:

- The flat roof made with $20 \mathrm{~cm}$ heavy concrete block, $8 \mathrm{~cm}$ screed and $1 \mathrm{~cm}$ asphalt.

- The walls made with $15 \mathrm{~cm}$ brick, $5 \mathrm{~cm}$ insul and $6 \mathrm{~cm}$ plaster.

- The ground made with $0.5 \mathrm{~cm}$ floor, $6 \mathrm{~cm}$ stone, $4 \mathrm{~cm}$ silence, $24 \mathrm{~cm}$ concrete and 6 -cm concrete.

- The house have a eight double glazing windows with $3 \mathrm{~m}^{2}$.

- The windows are primarily south-facing to block direct sunlight during the summer [20].

The house model was imported into TRNSYS simulation studio, Figure 4 clearly shows the dimensions of the building thermal zones.

\subsubsection{GHP description}

In the proposed GSHPs under study, the parameters of the water-to-water heat pump model were determined based on the product specification available from the manufacturers and based on the design load so that its nominal capacity is adequate for the thermal loads of the building. The reversible heat pump is designed to satisfy the cooling demands of a large area, so to adapt it to our case study, we used a water storage tank (insulating tank, variable inlets) of $1 \mathrm{~m}^{3}$ to increase the thermal inertia of the system. The storage tank is directly connected to the two inputs of the GHP unit and on the other hand linked through a small circulation pump to ensure the circulation of water in the RF system.

\subsubsection{Radiant floor system}

In the TRNSYS program, the TRNBuild model is equipped with a radiant floor system that provides cooling to the various zones, the circuit of the RF system consists of a multilayer (Cross-linked polyethylene) heat exchanger with $0.017 \mathrm{~m}$ of outside diameter and with a $0.02 \mathrm{~m}$ distance between the pipes. The heat exchangers are distributed throughout the ground floor to ensure a uniform internal temperature distribution. 


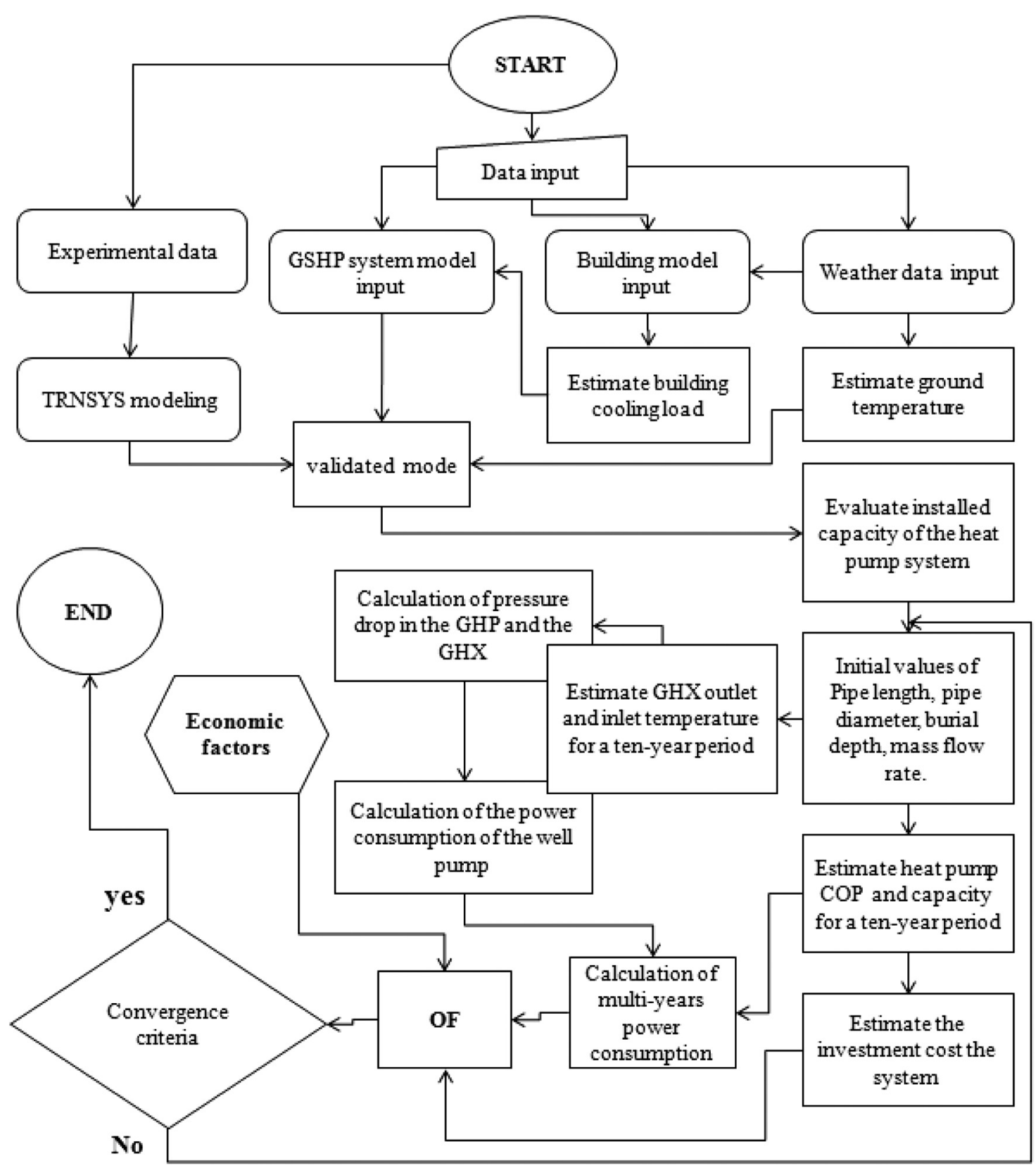

Fig. 2. Block diagram of the design procedure.

\subsubsection{Ground source heat exchanger}

The proposed GSHPs uses a geothermal field as a heat sink designed according to the thermal loads of the house, this field is composed of straight ground heat exchanger installed horizontally at different depths in the ground. It consists of HDPE (high-density polyethylene, PE 100, type SDR11) pipe with different inner diameters where the circulating fluid (water with anti-freezer) flows as a heat transfer fluid.

\subsubsection{Weather data}

As already mentioned in the previous sections, the meteorological factors are a very important database to represent the most important physical phenomena related to the calculation of thermal loads and soil temperatures. For TRNSYS thermal modeling, the weather data was collected from weather stations and converted to TMY2 data format by an actual meteorological data processor.

\subsubsection{Annual energy consumption}

In this work, the dailay load profile was categorized into three time periods as illustrated in Figure 5, this categorization was mainly designed for ground recharge purposes by assuming that there is no cooling demand during the transition periods. In order to calculate the cooling thermal load, the cooling thermostat was set as 


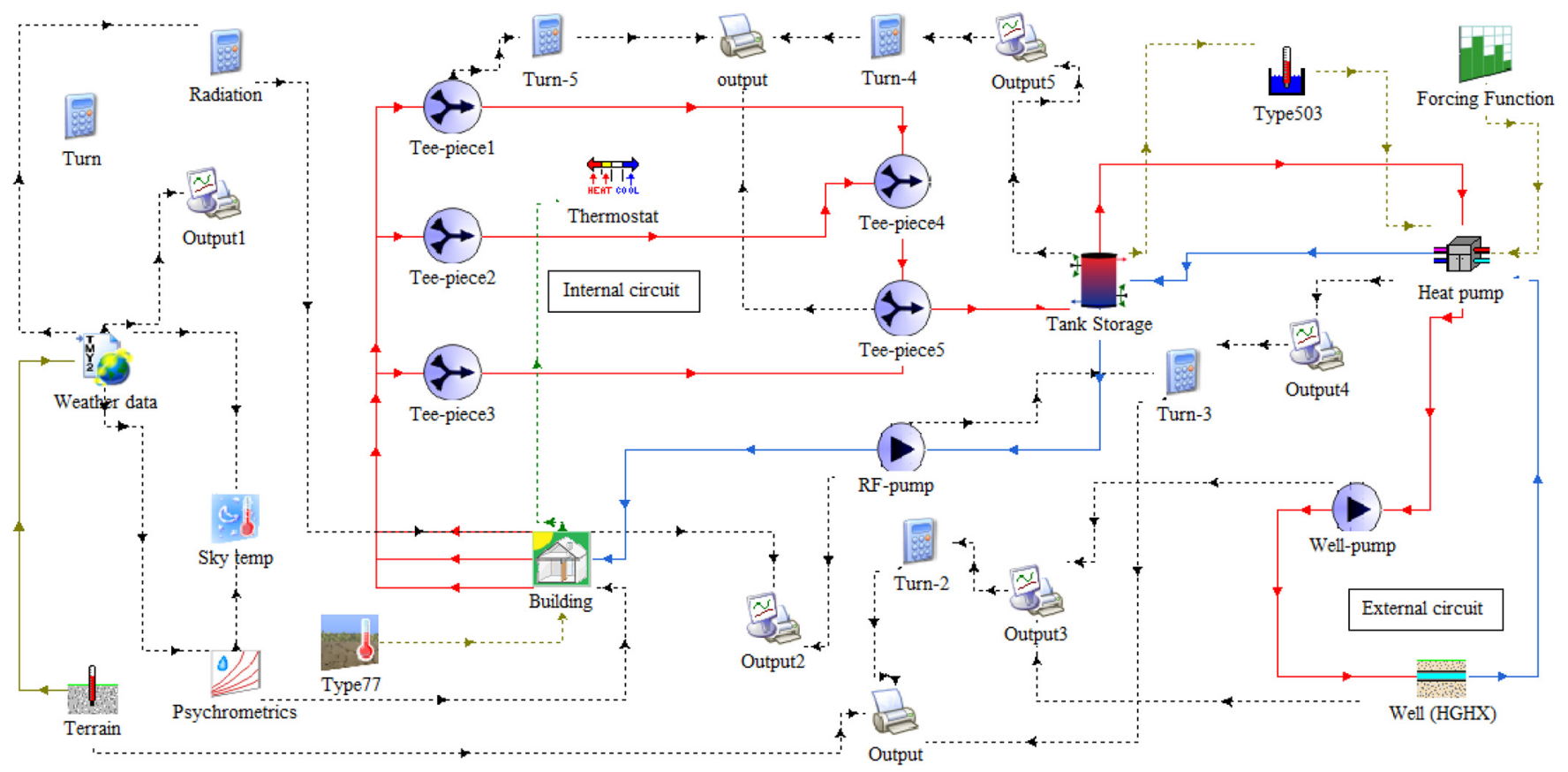

Fig. 3. The model of HGSHP system developed in TRNSYS.

Table 3. The technical information of the main system components and TRNSYS types.

\section{TRNSYS type}

Type 56

Type 668

Type 556

Type $4 \mathrm{c}$

Type $3 \mathrm{~b}$

Type $14 \mathrm{~h}$

Type 501

Type 109-TMY2

Type $65 \mathrm{c}$

Type $25 f$
Type description

Multi zone building model with Refreshing Floor

Reversible water-to water heat pump

Simple horizontal ground heat exchanger

Thermal storage tank with an immersed heat exchanger

Single speed circulating pump

$\mathrm{ON} / \mathrm{OFF}$ differential controller

Soil temperature profile

Formatted file data reader

Graphical plotter

Printer with output file $26^{\circ} \mathrm{C}$ from 10 to 18 and 20 to 06 for all the spaces according to the thermal comfort standards [21].

Figure 6 shows the variation of the annual building cooling loads which were obtained using the TRNSYS simulation software based on the weather data of the south climate. According to the load simulation results, the cooling period started from 15 May to 31 October, the remaining periods were considered as transition and heating periods.

\subsubsection{Variation of the soil temperature}

The design of geothermal heat exchangers depends strongly on the undisturbed soil temperature (i.e. the soil temperature before any heat injection or extraction) as they affects soil resistance [13,14], which limits the heat exchange between the soil and the GHX wall [7], and thus affects the GSHP performance coefficient as well as the design parameters of the ground heat exchanger.

The initial subsurface temperature distribution $T_{s}$ can be computed as a function of the time of year and the depth below the ground surface as the following correlation [14]:

$$
\begin{aligned}
T_{s} & =\bar{T}_{s}-A_{s} \times \exp \left[-Z\left(\sqrt{\frac{\pi}{365 \times \alpha_{\text {sol }}}}\right)\right] \\
& \times \cos \left[\frac{2 \pi}{365}\left(t_{\text {now }}-t_{\text {shift }}-\frac{Z}{2} \times \sqrt{\frac{365}{\pi \times \alpha_{\text {sol }}}}\right)\right]
\end{aligned}
$$

$\bar{T}_{s}$ is the mean value of the ground surface temperature for a location of Ouargla city over an entire year, $A_{s}$ is the amplitude that the surface temperature experiences 


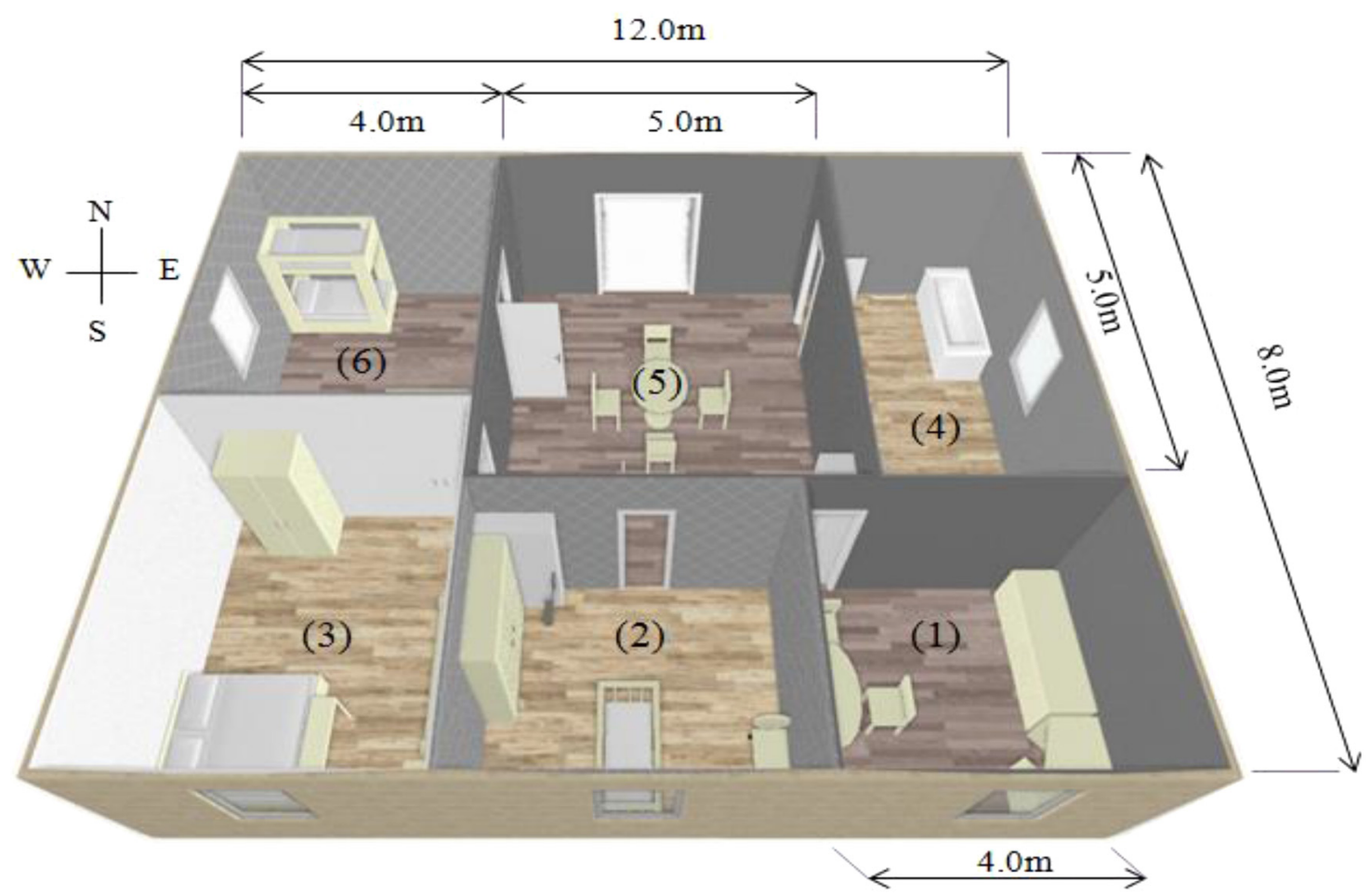

Fig. 4. 3D schematic view of the typical building (1): Zoon1 (kitchen), (2), (3), (6): Zoon2, 3, 6 (bedrooms), 4: Zoon4 (bathroom) and (5): Zonn5 (living room).

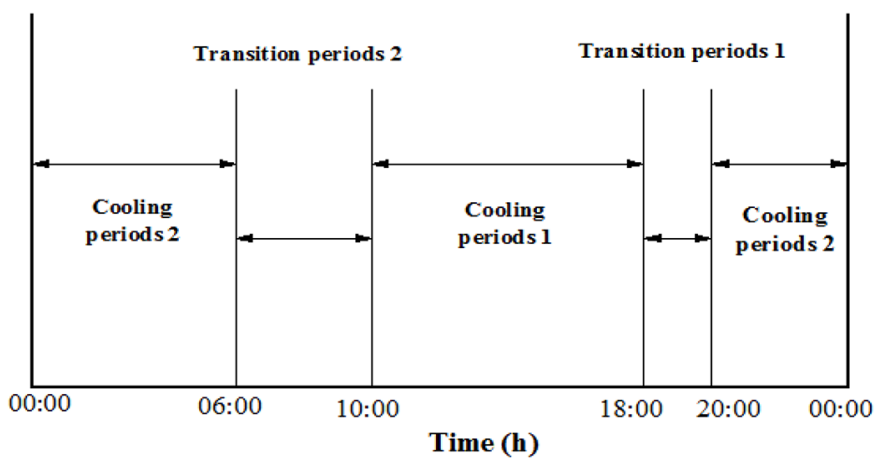

Fig. 5. Daily cooling and transition periods.

throughout a year at the location, the parameter $t_{\text {shift }}$ is the difference in time between the beginning of the year and the occurrence of the minimum surface temperature, $\alpha_{\text {sol }}$ is the thermal diffusivity of the ground $\left(\frac{m^{2}}{d a y}\right)$. The thermal properties of the soil were obtained referring to Table 4.

Figure 7 shows the undisturbed soil temperature profiles over a year for the given climate. It can be observed that the amplitude of the soil temperature signal decreases as the depth increases. In the upper $3 \mathrm{~m}$, where soil temperature is affected by the external factors of climatic conditions, the soil has a big thermal slope. In deeper distances that correspond to the thermally stable zone, the soil mean temperature is almost constant.

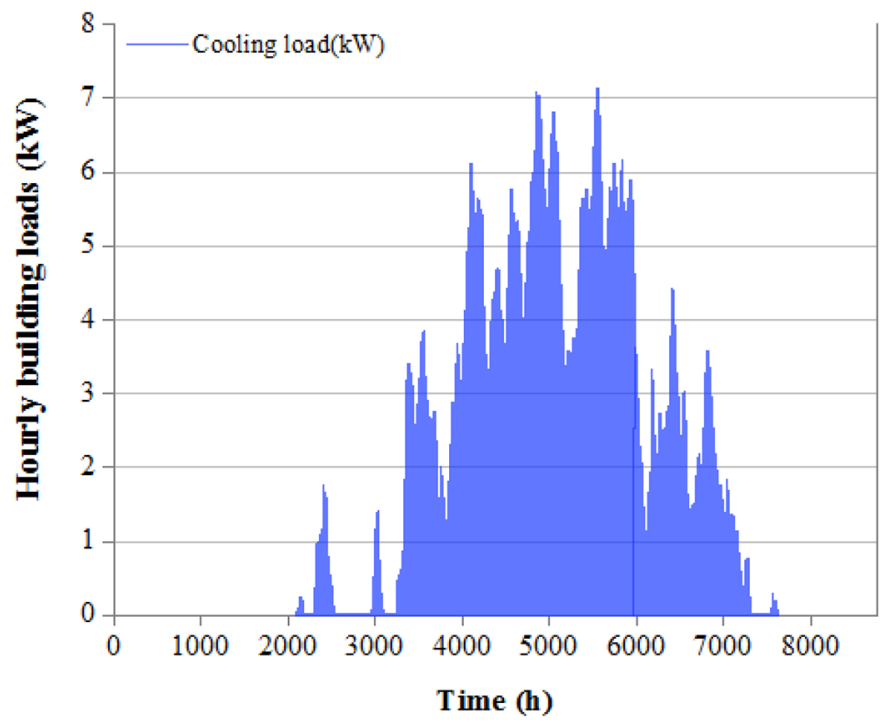

Fig. 6. Hourly coolin loads of the proposed building.

\subsection{Model validation}

This section presents the validation of TRNSYS type against experimental measurements of one of the three heat exchangers of the CRTEn ground source heat pump projet. For this purpose, all the technical characteristics of the experimental device as well as the climate teste building have been integrated into the developed TRNSYS model. 
Table 4. The soil properties.

\begin{tabular}{ll}
\hline Parameter & Values \\
\hline Thermal conductivity of soil $(\mathrm{W} / \mathrm{m} . \mathrm{K})$ & 0.93 \\
Specific heat of soil $(\mathrm{J} / \mathrm{kg} . \mathrm{K})$ & 1390 \\
Density of soil $\left(\mathrm{kg} / \mathrm{m}^{3}\right)$ & 1780 \\
Average surface temperature $\left({ }^{\circ} \mathrm{C}\right)$ & 23.5 \\
Day of minimum surface temperature & 32 \\
\hline
\end{tabular}

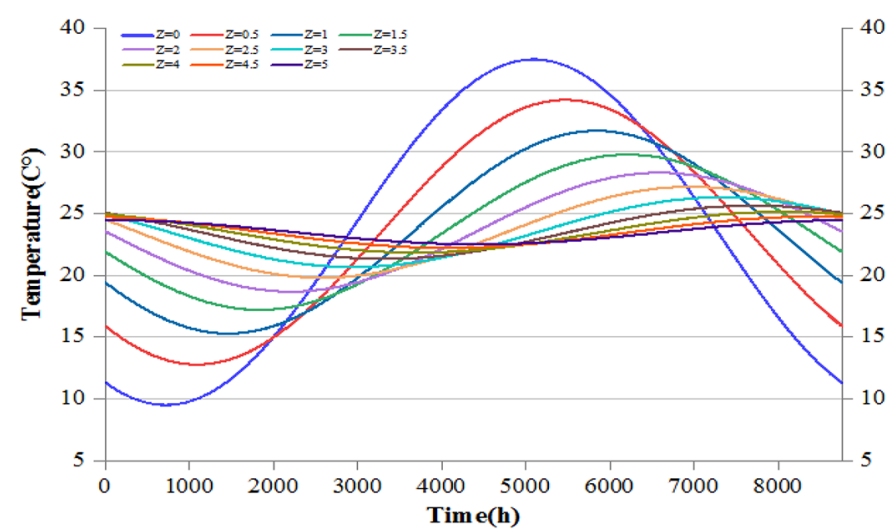

Fig. 7. Variations of soil temperature with depth (m), Ouargla city.

The following assumptions have been made:

- The model has been validated with the consideration of the experimental measurements of mass flow, pipe length, pipe diameter, burial depth as inputs for the HGHX type.

- The number of horizontal nodes has been increased in order to increase the accuracy at the expense of simulation time.

- Average value of function (time interval) was imposed by the library (TESS) controller to correctly reproduces the evolution of the on/off cycle of the heat pump unit over the simulation periods.

- In order to ensure good accuracy in predicting the response of the drill, the thermophysical properties of the soil and the backfill material around the horizontal buried pipes were precisely determined before being integrated in the HGHX type.

\subsubsection{CRTEn ground source heat pump projet}

The experimental system (Fig. 8) installed in a test office of the Laboratory of Thermal Processes (LPT) at the Research Center and Technologies of Energy (CRTEn). The system consists of a GSHP unit manufactured by CIAT that provides the air conditioning for $12 \mathrm{~m}^{2}$ area. The GHP with a cooling capacity of $12.7 \mathrm{~kW}$ is connected to an internal and external circuits. The internal circuit includes a radiant floor system, a water storage tank and a circulation pump. On the other hand, the external circuit comprises a circulation pump and three buried heat exchangers (GHX):

- Heat exchanger of length $25 \mathrm{~m}$ buried at $1 \mathrm{~m}$ of depth.

- Heat exchanger of length $50 \mathrm{~m}$ buried at $1 \mathrm{~m}$ of depth.

- Heat exchanger of lenght $50 \mathrm{~m}$ buried at $0.6 \mathrm{~m}$ of depth.

- Heat exchanger of length $100 \mathrm{~m}$ buried at $1 \mathrm{~m}$ of depth.

A detailed description of the installation, the measurement equipments and the particular conditions of its operation is provided in Refs. [22-24].

\subsubsection{Experimental verification results}

In order to test the reliability of the simulation model that we have developed, the validation results presented in this section will mainly aim to evaluating the ability of the model to qualitatively represent the observed physical phenomena in pilot plan experimentation.

The experimental measurements has been compared against the simulated inlet and outlet fluid temperature of the GHX, the heat exchange rate to ground and the coefficient of performance. Figure 9 reports the relativeerror analysis between experimental and simulation results, we can observe from this illustration that the maximum error between the simulation and experimental performance coefficient does not exceed $4.9 \%$, the same for the outlet and inlet water temperature and the heat exchanger rate, the maximum relative-error reaches about $1.4 \mathrm{C} \%, 2.3 \mathrm{C} \%$ and $0.5 \%$, respectively. This results showing that the TRNSYS model is able to reproduce the thermal behavior of the HGSHP with a high accuracy. Therefore, it can be concluded that by means of the developed model of GSHP in TRNSYS environment, the GHP system and the drill outputs can be pre-investigated individually based on meteorological and geological databases.

\section{ASHRAE guidelines constraints}

In the ASHRAE design methods, the water mass flow rate and the outlet ground heat exchanger temperatures constraints applied in optimization procedures according to practical conditions for the cooling mode are [25]:

- The maximum value of the $T_{\text {out }-G H X}$ is $11-17^{\circ} \mathrm{C}$ greater than the undisturbed soil temperature $\left(T_{s}\right)$ to guarantee the proper heat exchange between the soil and hot water and refrigerant in condenser.

- In warm climates $\left(T_{s}>15^{\circ} \mathrm{C}\right)$ the optimal level tends to the minimum for this range $\left(11^{\circ} \mathrm{C}\right)$.

\section{Results and discussions}

The TRNSYS model presented and validated above is used in this section to envisage the effectiveness of the HGSHPs for air-conditioning a typical house in Saharan climate. The first part was conducted to determine the optimal GHXs design using a thermal-economic optimization. In the second part, the optimized values of all the design 


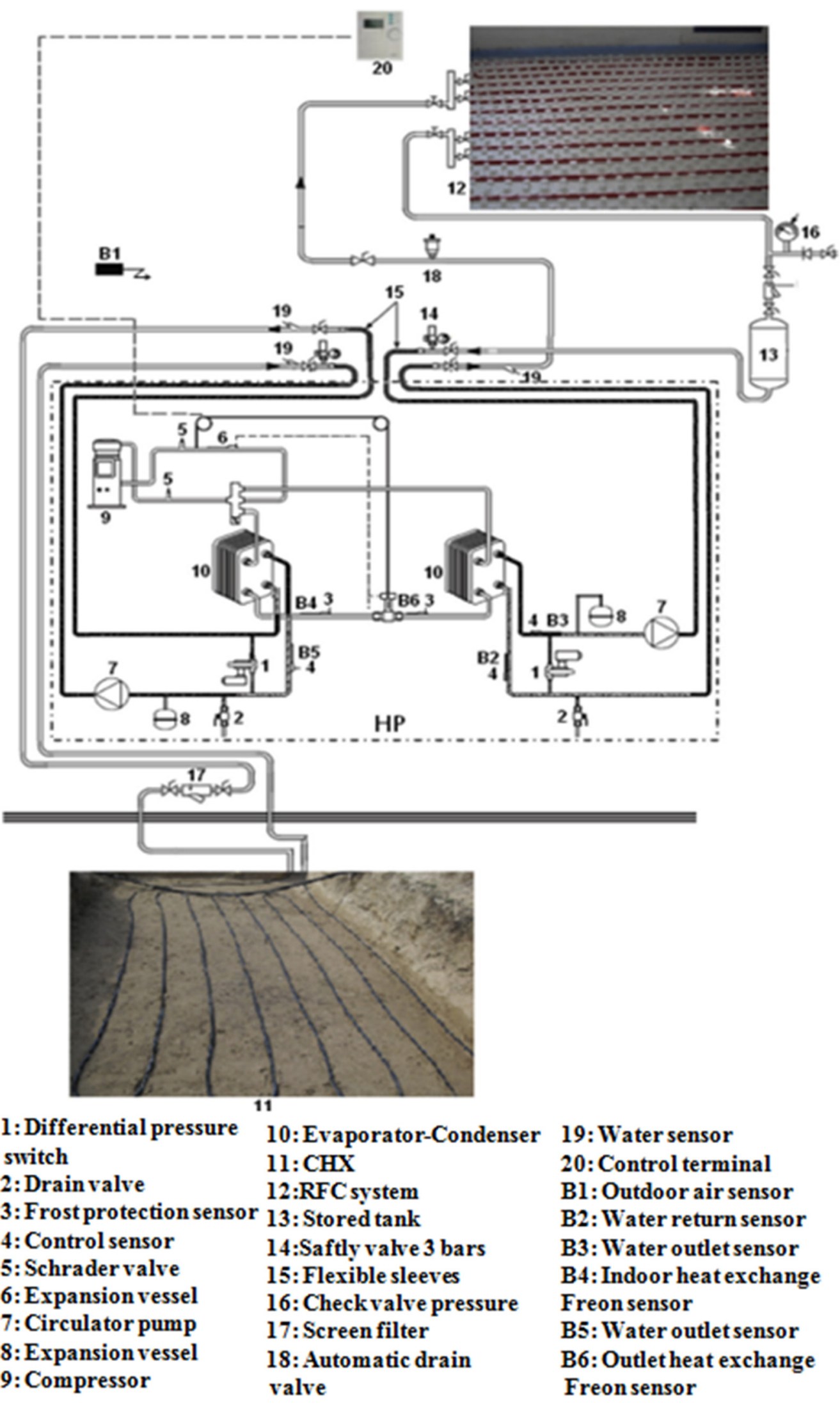

Fig. 8. Schematic diagram of the HGSHP experimental system (modified from [23]). 


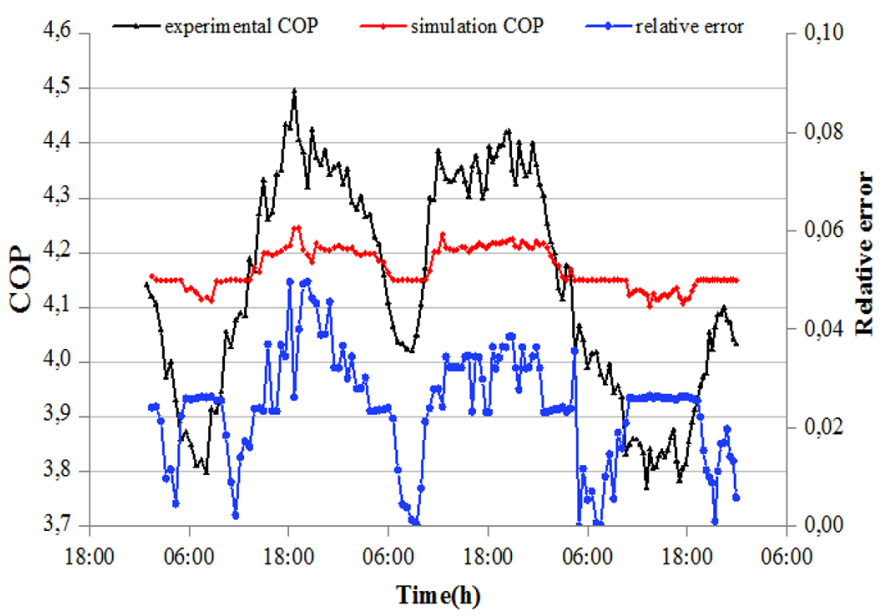

Fig. 9. Experimental vs numerical coefficient of performance of the GSHP.

parameters were performed in the HGSHP model that used for cooling a residential building with $95 \mathrm{~m}^{2}$ of surface in the city of Ouargla, Southeast of Algeria.

\subsection{Optimization results}

The optimal design of the GHX is obtained by considering the long time operating costs and the first investment costs simultaneously under technical and economic conditions. Thus, the effects of the design parameters such as the pipe length, pipe diameter, burial depth and mass flow rate on both the objective function and the performance of GSHP were investigated in ten years of cooling period in different cases as summarized in the Table 5.

The system operating conditions and the constant economical factors were collected in Table 6 . The obtained optimum values of all effective parameters in objective function are listed in Table 7 .

\subsubsection{Effect of the pipe length}

In this section, the effects of pipe length on the thermal and economic performance of the HGSHPs, were investigated by assuming constant mass flow rate, pipe diameter and burial pipe depth (Cases 1-9).

The coefficient of performance of the GSHP and the objective function values are shown in Figure 10 (left) and (right), respectively. As expected, the results demonstrates that an increase in pipe length leads to an increase in the thermal performance of the heat pump and the first investment cost. In the initial stage, the electric power consumption of the compressor decreases with the increase of pipe length, which reduces the objective function until getting a minimum point at $500 \mathrm{~m}$ of pipe length (Case 4 , optimal point). After this stage, the system investment caused by increased heat exchanger area as well as the excavation works exceeds the decrease of operating cost which explain the increase in the objective function in this range of pipe lengths.
Table 5. Design parameters of all cases.

\begin{tabular}{lllll}
\hline Cases & $\mathrm{Z}(\mathrm{m})$ & $\begin{array}{l}\dot{m}_{w-G H X} \\
(\mathrm{~kg} / \mathrm{s})\end{array}$ & $\begin{array}{l}L_{G H X} \\
(\mathrm{~m})\end{array}$ & $\begin{array}{l}D_{i-G H X} \\
(\mathrm{~m})\end{array}$ \\
\hline Case 1 & 1 & 0.5 & 200 & 0.029 \\
Case 2 & & & 300 & \\
Case 3 & & & 400 & \\
Case 4 & & & 500 & \\
Case 5 & & & 600 & \\
Case 6 & & & 700 & \\
Case 7 & & & 800 & \\
Case 8 & & & 900 & \\
Case 9 & & & 1000 & \\
Case 10 & & & 500 & 0.018 \\
Case 11 & & & & 0.0227 \\
Case 12 & & & & 0.029 \\
Case 13 & & & & 0.0363 \\
Case 14 & 0.5 & & & \\
Case 15 & 1 & & & \\
Case 16 & 1.5 & & & \\
Case 17 & 2 & & & \\
Case 18 & 2.5 & & & \\
Case 19 & 3 & & & \\
Case 20 & 1 & 0.25 & & \\
Case 21 & & 0.5 & & \\
Case 22 & & 0.75 & & \\
Case 23 & & 1 & & \\
Case 24 & & 1.25 & & \\
Case 25 & & 1.5 & & \\
Case 26 & & 1.75 & & \\
Case 27 & & 2 & & \\
\hline
\end{tabular}

\subsubsection{Effect of the pipe diameter}

The variations of the objective function and the performance coefficient of the GSHP system as functions of pipe diameter in constant mass flow rate, burial depth and pipe length (Cases 10-13) are shown in Figure 11. Results illustrate that the objective function and the COP of the GSHP were directly affected by pipe diameter values. The electric power consumption of the compressor and the well pump decreases with the increase of pipe diameter, indicating a degradation in the objective function of about $63.16 \%$ from 0.02 to $0.04 \mathrm{~m}$ of outer pipe diameter.

\subsubsection{Effect of the burial depth}

To determine the optimal burial depth in which we must put the GHX pipes a series of simulations were carried out. The results which plotted the objective function and the COP of the GSHP as functions of the burial pipe depth in constant mass flow rate, pipe diameter and pipe length (Cases 10-19) are shown in Figure 12. With increasing the burial depth, the electric power consumption of the 
Table 6. The list of input parameters used in economic analysis.

\begin{tabular}{ll}
\hline $\mathrm{T}_{\mathrm{c}}=720(\mathrm{~h} / \mathrm{y})$ & $C_{\text {heatpump }}=998 \$$ for cooling capacity of $5.8-9(\mathrm{KW})$ \\
\hline$\tau_{c}=4320(\mathrm{~h} / \mathrm{y})$ & $C_{\text {heatpump }}=1057 \$$ for cooling capacity of $9-11.3(\mathrm{KW})$ \\
$n=10(\mathrm{y})$ & $C_{\text {heatpump }}=1198 \$$ for cooling capacity of $11.3-15(\mathrm{KW})$ \\
$i=10 \%$ & $C_{\text {heatpump }}=1129 \$$ for cooling capacity of $15-17.5(\mathrm{KW})$ \\
$\eta_{\text {pump }}=80 \%$ & $C_{\text {heatpump }}=1926 \$$ for cooling capacity of $17.5-22.6(\mathrm{KW})$ \\
$a_{1}=6\left(\$ / \mathrm{m}^{2}\right)$ & $E_{\text {traiff }}=0.014 \$$ for power consumption of $0-125(\mathrm{KWh})$ \\
$e=10 \%$ & $E_{\text {traiff }}=0.034 \$$ for power consumption over $125(\mathrm{KWh})$ \\
\hline
\end{tabular}

Table 7. The list of optimum design parameters including the results values of elements of the objective function.

\begin{tabular}{ll}
\hline$L_{G H X}=500(\mathrm{~m})$ & $C R F=0.1627$ \\
\hline$D_{i-G H X}=0.0363(\mathrm{~m})$ & $C_{\text {elec }}=11649.68(\$)$ \\
$Z=1(\mathrm{~m})$ & $C_{\text {heatpump }}=1926(\$)$ \\
$\dot{m}_{w-G H X}=1(\mathrm{~kg} / s)$ & $C_{\text {pump }}=360.18(\$)$ \\
$W_{\text {com }}=18.5(\mathrm{~kW})$ & $C_{\text {earthworks }}=2250(\$)$ \\
$W_{\text {pump }}=1.85(\mathrm{~kW})$ & $T A C=2850.66(\$)$ \\
$E=21210(\mathrm{kWh} / y)$ & $O F=0.00568108(\$ / \mathrm{kWh})$ \\
\hline
\end{tabular}

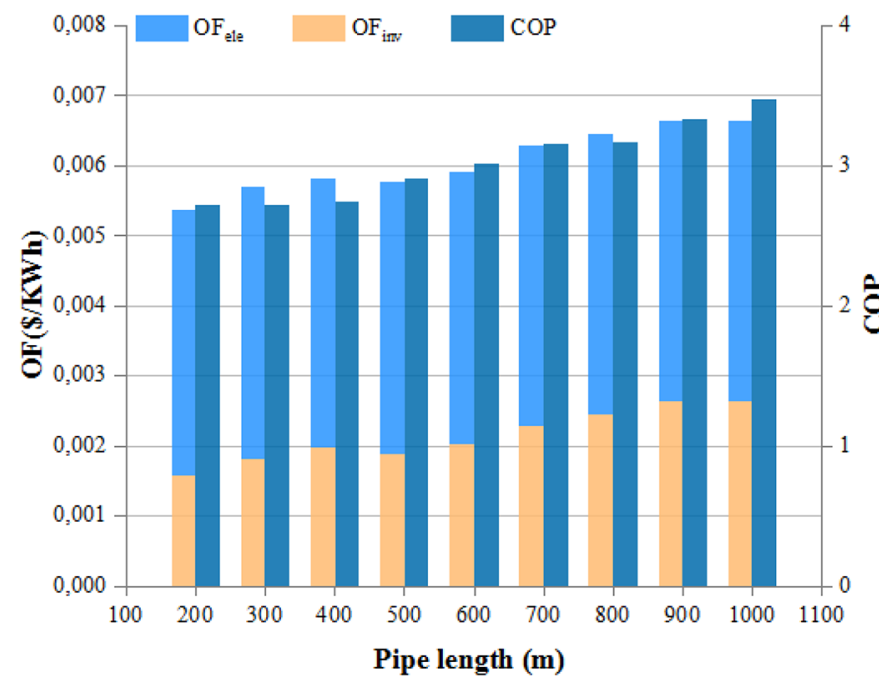

Fig. 10. Effect of HGHX length on the objective function and the COP of the GSHP.

compressor decreases and the COP increases as a result of the improvement in the amounts of heat transferred to soil in the lower depths. But it is clear that from $1 \mathrm{~m}$ of depth (Case 11, optimal point), the investment cost caused by increased the cost of earthworks is far exceeds the decrease of operating cost, which explain the increase in the objective function by more than $7.22 \%$ from 1 to $3 \mathrm{~m}$ of burial depth.

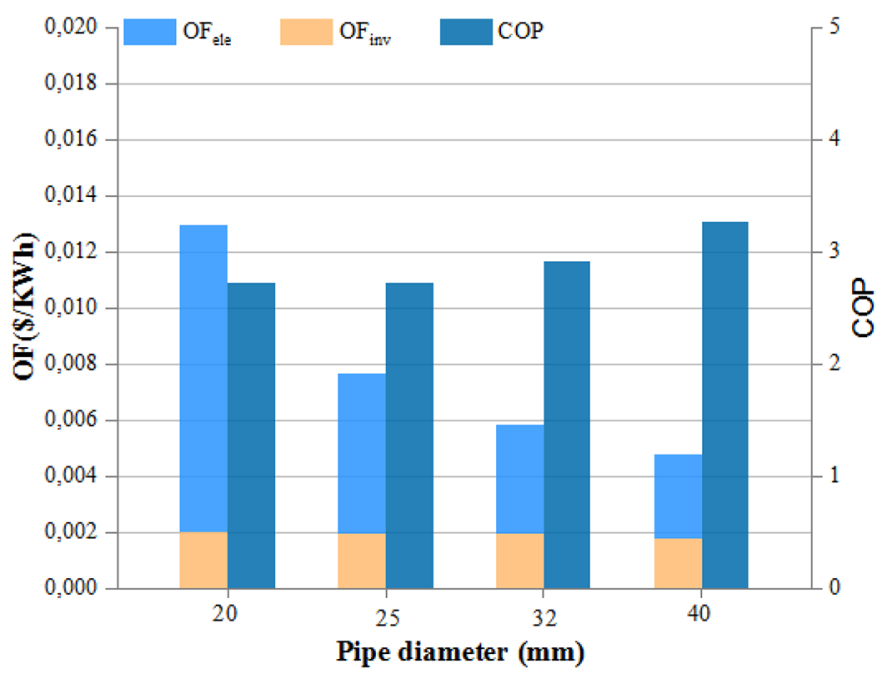

Fig. 11. Effect of HGHX diameter on the objective function and the COP of the GSHP.

\subsubsection{Effect of the mass flow rate}

Figure 13 displays the objective function and the coefficient of performance of the GSHP as function of mass flow rate in constant burial depth, pipe diameter and pipe length (Cases 20-27). In the initial stage (Cases 20-23), the COP increases and the electric power consumption of the well pump decreases with the increase of mass flow rate of water circulating in the GHX, which explain the decline in the objective function until getting a minimum value at $1 \mathrm{~kg} / \mathrm{s}$ (optimal point). In higher mass flows rate (Cases 24-27), the pressure drop in the GHX was increased gradually with the increase of fluid velocity that increased the electric power consumption of the well pump and simultaneously reduced the $\mathrm{COP}$ values.

\subsection{The optimized HGSHPs operation analysis}

In this section, investigating the effects of the all optimum design parameters on the operation of the HGSHPs were performed. The effect of the long time HGSHPs operation on the drill outputs and soil temperature were assessed as follows: 


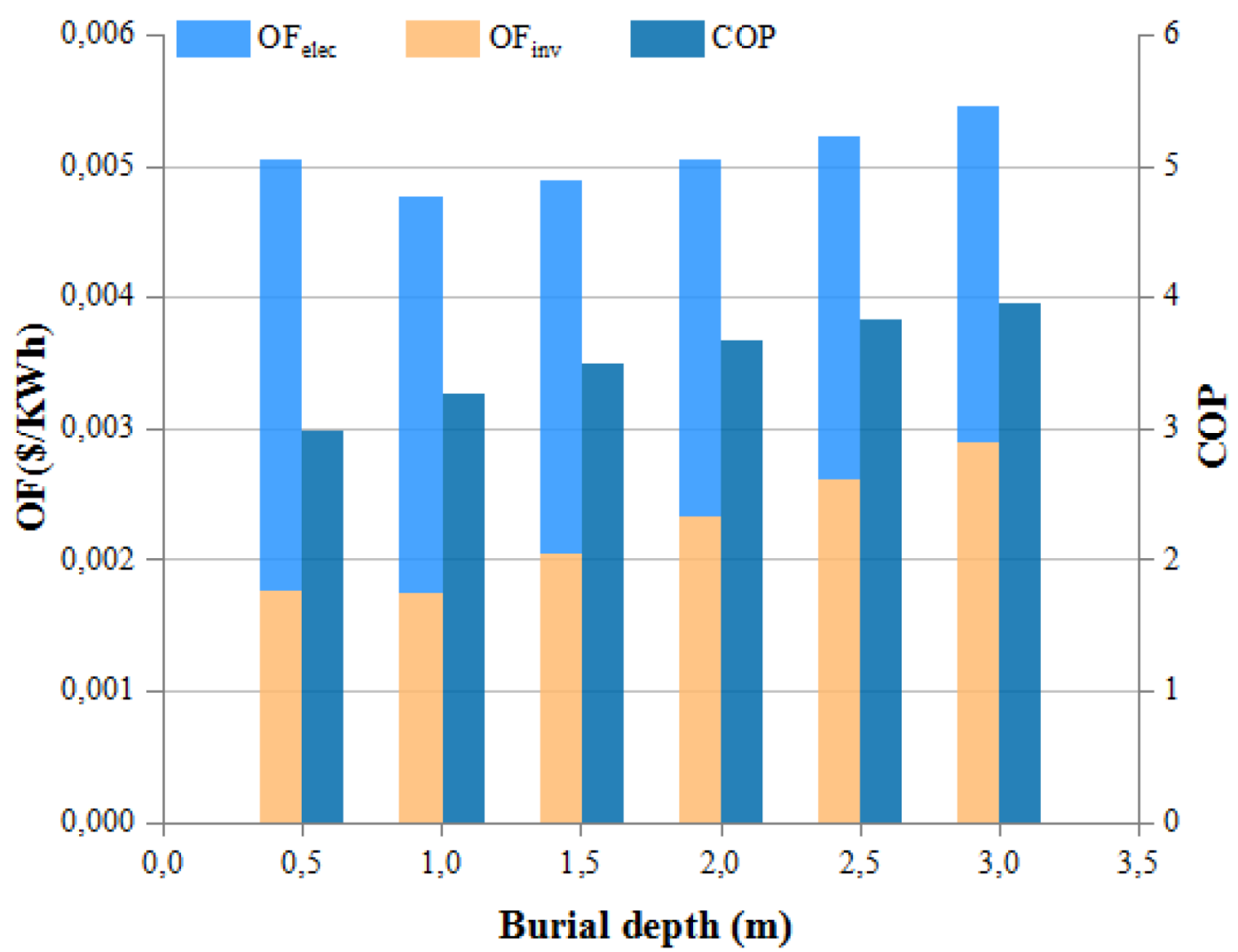

Fig. 12. Effect of burial depth on the objective function and the COP of the GSHP.

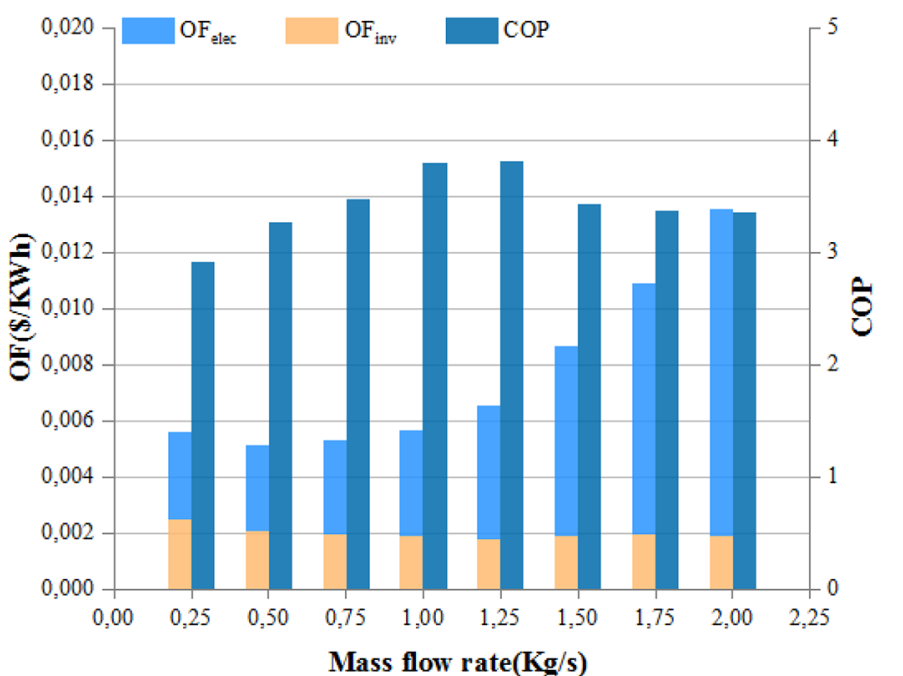

Fig. 13. Effect of mass flow rate on the objective function and the COP of the GSHP.

\subsubsection{Drill outputs and soil temperature estimates}

The inlet/outlet GHX temperatures and the average soil temperature of the optimized HGSHPs for the first year and for ten years in Ouargla were shown in Figures 14-16.
The inlet and outlet GHX temperatures for ten years presented relatively parallel trend and the average soil temperature around the GHX was stably equal in all this period. Therefore, the employment of the HGSHPs was very suitable for buildings of Ouargla in the long term. As shown in Figure 14b, the maximum difference between the outlet and inlet GHX fluid temperature ranging between 22 and $22.2^{\circ} \mathrm{C}$ and the maximum difference between the outlet GHX temperature and soil temperature is $14.5^{\circ} \mathrm{C}$. Due to the very hot climate, these values showing that the simulation results present an acceptable agreement with ASHRAE constraints.

The heats injected into ground during the cooling season is shown in Figure 17. Results illustrate that the heats rejected from the GHX into ground vary between 0.37 and $83.6 \mathrm{~kW}$, which reflect the high potential of saharan territories for cooling buildings.

\subsubsection{Building thermal conditions}

In order to show the rentability of optimized HGSHPs for refreshing the different typical building zones, we represent in Figures 18 and 19 the variations of indoor and outdoor climat conditions during a typical days of cooling mode (July 1 until July 30) in the first year of operation for different scenarios. 


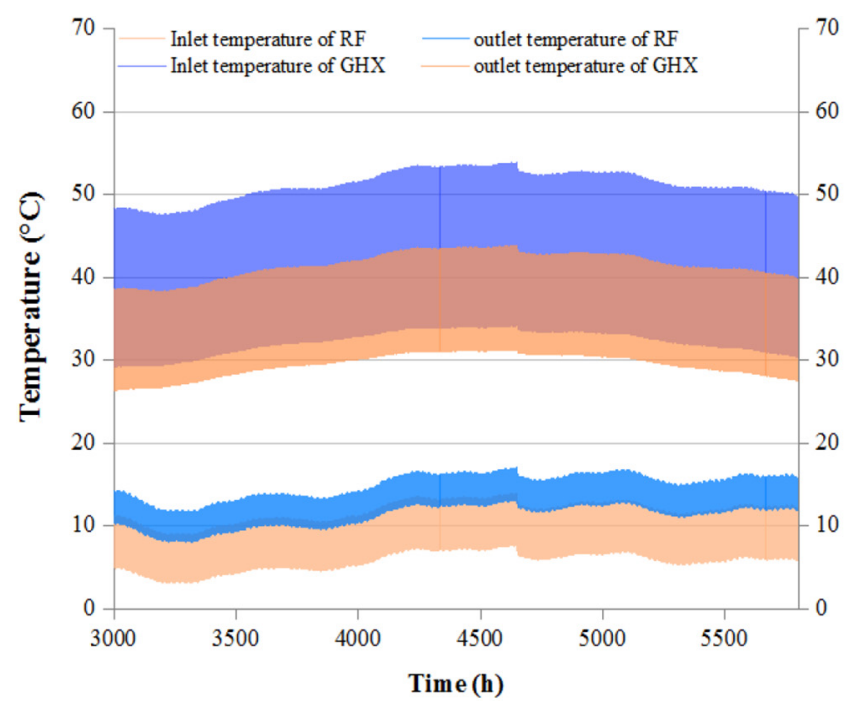

(a)

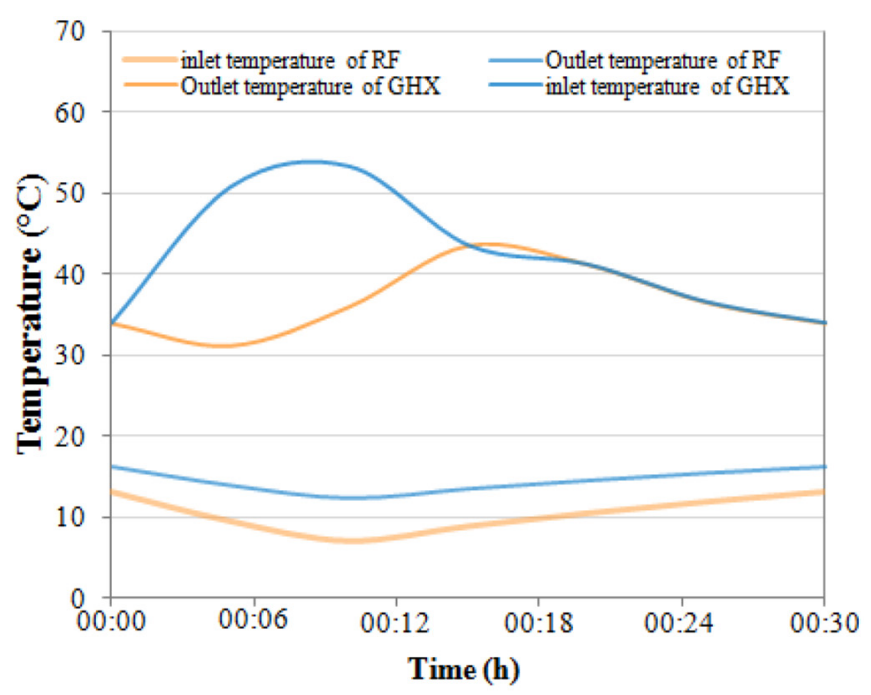

(b)

Fig. 14. Evolution of water temperatures at the external and the internal circuits in (a) the first year period, (b) typical day for $\mathrm{L}_{\mathrm{GHX}}=500 \mathrm{~W} / \mathrm{m}, \mathrm{D}_{\mathrm{i}-\mathrm{GHX}}=0.0363 \mathrm{~m}$ and $\mathrm{Z}=1 \mathrm{~m}$.

In the first state, without the HGSHP conditioning system, it was observed that the indoor temperature vary between 37.44 and $41.96{ }^{\circ} \mathrm{C}$, while the indoor relative humidity ranges between $25.48 \%$ and $33 \%$, for an outside air temperature and relative humidity ranging between 25.92 and $48.72{ }^{\circ} \mathrm{C}$ and $10-57.96 \%$, respectively.

In the second state, with the HGSHP conditioning system, the indoor air temperature ranges between 23.5 and $27^{\circ} \mathrm{C}$ while the relative humidity values ranges between $58.31-73.97 \%$, this corresponding to a periodic change in the inlet and outlet RF system water temperature of about $6.95-13.1$ and $12.2-16.1^{\circ} \mathrm{C}$, respectively as shown in Figure 14. These results demonstrate the effectiveness of the HGSHPs for cooling in the selected climate that experience high-temperature days.

The simulation total heat absorbed from the building $\left(Q_{b}\right)$ is represented also in Figure 17. We can note from this figure that the absorbed heat can reach a maximum and a minimum values of 5.99 and $10.49 \mathrm{~kW}$, respectively, corresponding to the compressor on/off. These considerable values is mainly due to the high cooling loads of the building example.

\subsubsection{Energy consumption distribution and COP evaluations}

The COP and the operation power consumption of the optimized HGSHP system (including GSHP units, circulating pump in internal circuit and the circulating pump in external circuit) for the first year of cooling operation were shown in Figure 20a and 20b. The average COP of GSHP in cooling season was about 3.92. Based on this result, the energy efficiency ratio (EER) and seasonal energy efficiency ratio (SEER) of the HGSHPs which are especially important indicators in hot-dry climates can be calculated as 13.44 and 17.42 , respectively.

\section{Conclusions}

In this study, the feasibility of improving the performance of a GSHP cooling system coupled with HGHX for the weather conditions of a Saharan environment and more particularly in the southeastern desert of Algeria was evaluated. A thermal-economic modeling and optimization of the system were analyzed using both MATLAB code and TRNSYS software which were previously validated.

The effects of various parameters such as mass flow rate of circulating water, length and burial depth of the GHX on the performance of the GSHPs were analyzed for a ten-year period in order to obtain the most cost-effective design parameters of the HGHX. Furthermore, the effects of the optimum design parameters on the operation of the HGSHPs used for cooling a $95 \mathrm{~m}^{2}$ surface area was investigated. The following conclusions are achieved:

- According to the undisturbed soil temperature before any heat rejected, the soil thermally stable zone corresponds to depths more than $3 \mathrm{~m}$.

- Higher pipe length more than $500 \mathrm{~m}$ has no significant effect on the thermal performance of the HGSHPs and is also not economical.

- Increasing the burial depth more than $1 \mathrm{~m}$ greatly affects the first investment total cost by increasing the price of earthworks and excavation. For every $0.5 \mathrm{~m}$ of additional borehole depth the return on investment is deteriorated by $12 \%$, whereas the system COP performance is improved by $4.9 \%$. 

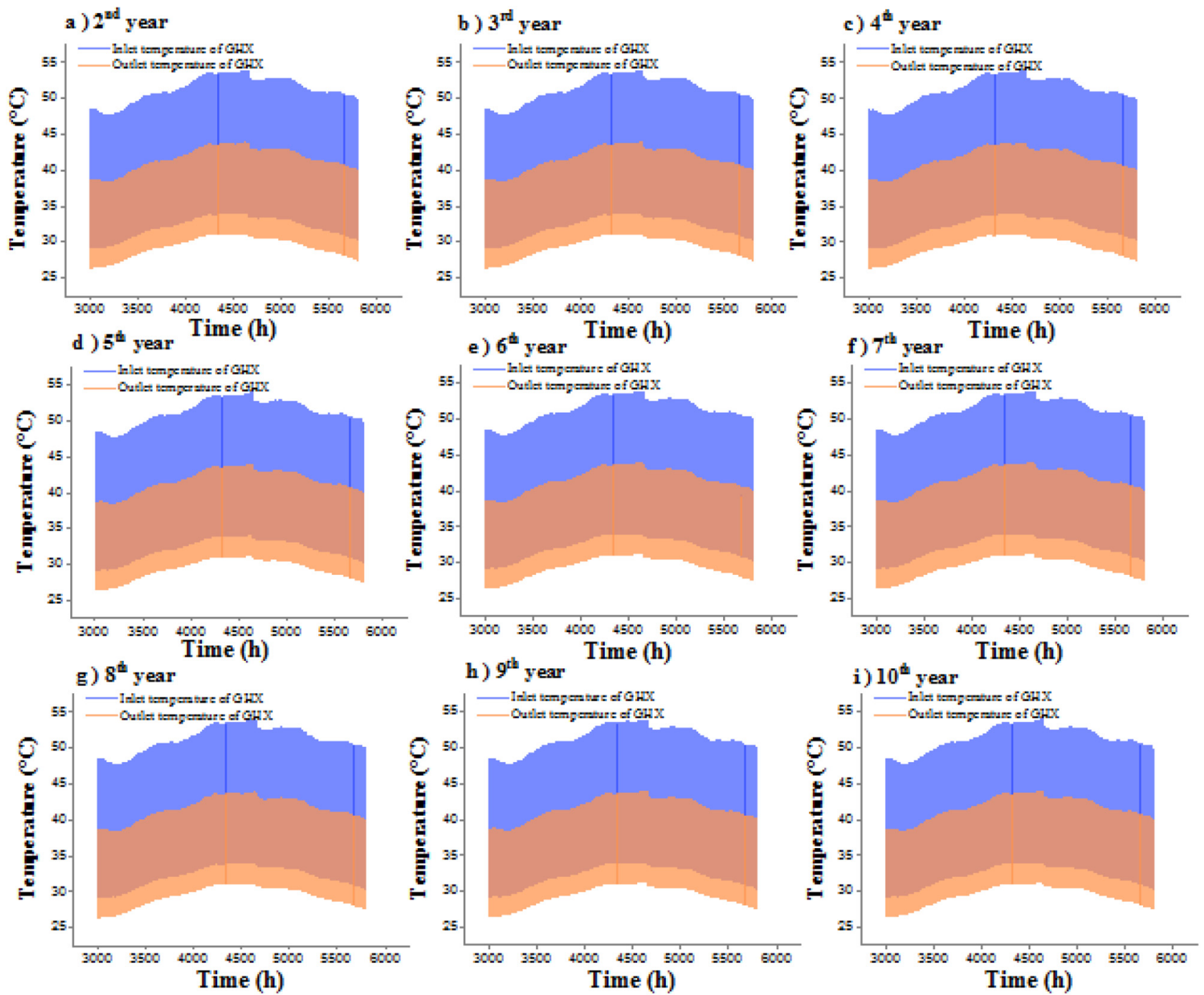

Fig. 15. Variation of fluid inlet, outlet ground heat exchanger water temperatures in nine years for $\mathrm{L}_{\mathrm{GHX}}=500 \mathrm{~W} / \mathrm{m}$, $\mathrm{D}_{\mathrm{i}-\mathrm{GHX}}=0.0363 \mathrm{~m}$ and $\mathrm{Z}=1 \mathrm{~m}$.

- The thermal performance coefficient decreases and the electric power consumption increases as the pipe diameters decrease. The small pipe diameters are not practical.

- The electric power consumption of the well pump increases sharply when the water velocity in the GHX pipe increases. Lower mass flow rates $(1-1.5 \mathrm{~kg} / \mathrm{s})$ are more suitable for GSHP operation in this case.

- For ten-year economical operations of HGSHPs, suggested values for pipe length, burial depth, pipe diameter and mass flow rate for this case are 500,1, $0.0363 \mathrm{~m}$ and $1 \mathrm{~kg} / \mathrm{s} \mathrm{m}$ respectively.

- According to outlet/inlet GHX temperature of buried pipes and soil temperature for 10 years operation, the HGSHPs showed excellent and stable performance. Therefore, the horizontal ground source heat pump with radiant floor as heat distribution system could be recommended for cooling applications in Saharan areas in the long term.
- The average value of the COP for ten years operation were found to be 3.89 . It represents a high system performance when compared to other traditional techniques.

- The use of HGHX coupled GSHP as an air conditioning system with improved values of the most-cost effective design parameters lead to diminished the indoor temperature of about $14.96^{\circ} \mathrm{C}$ and increased the relative humidity by more than $40.97 \%$ compared to the case without HGSHP cooling system.

- As an estimation of the geothermal potential of the Saharan territories, the water temperature drop between the inlet and the outlet of the GHX reach a maximum value ranging between 22 and $22.2^{\circ} \mathrm{C}$, this can be translated to an amount of heat rejected to the ground when the compressor switches on reached $83.6 \mathrm{~kW}$ which reflected the importance of exploitable shallow geothermal energy in the studied area. 


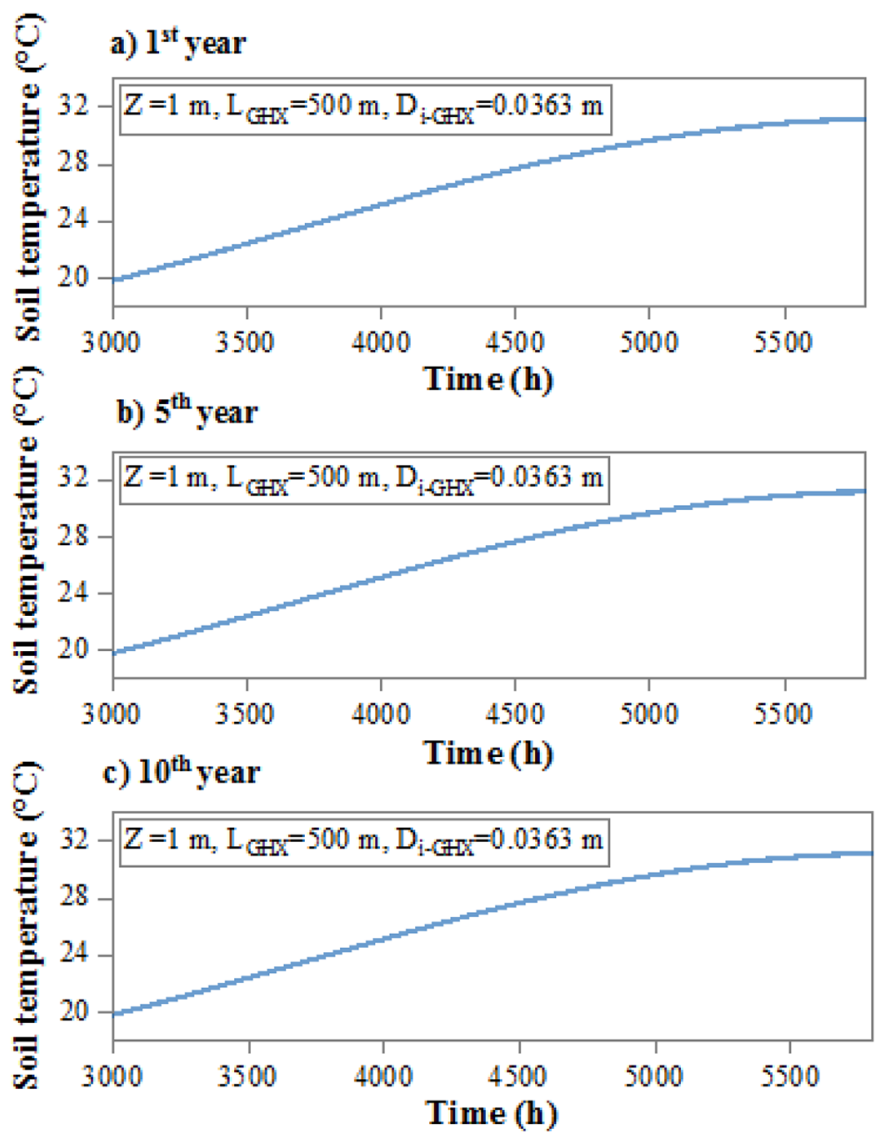

Fig. 16. Variation of average soil temperature surrounding the ground heat exchanger at the first, fifth and tenth year.

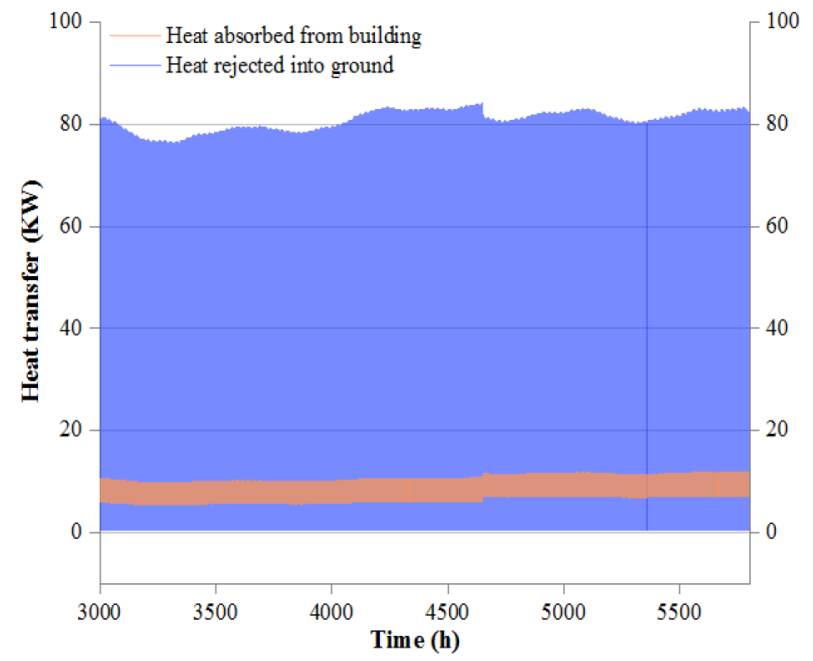

(a)

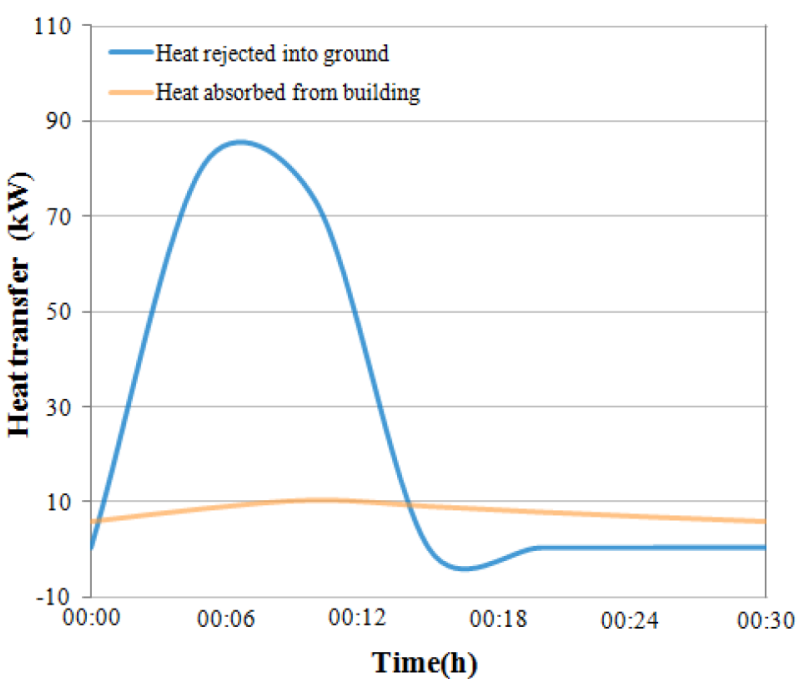

(b)

Fig. 17. Evolution of the heat injected into ground and the heat rejected from building in (a) the first year period, (b) typical day for $\mathrm{L}_{\mathrm{GHX}}=500 \mathrm{~W} / \mathrm{m}, \mathrm{D}_{\mathrm{i}-\mathrm{GHX}}=0.0363 \mathrm{~m}$ and $\mathrm{Z}=1 \mathrm{~m}$. 


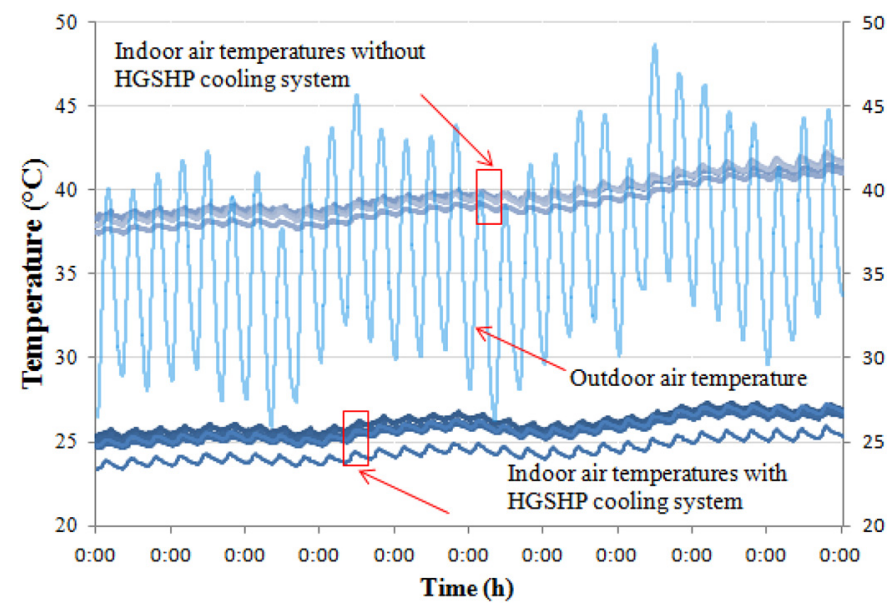

Fig. 18. Comparison between indoor and outdoor temperatures in a typical days (July 1 until July 30) for $\mathrm{L}_{\mathrm{GHX}}=500 \mathrm{~m}$, $\mathrm{D}_{\mathrm{i}-\mathrm{GHX}}=0.0363 \mathrm{~m}$ and $\mathrm{Z}=1 \mathrm{~m}$.

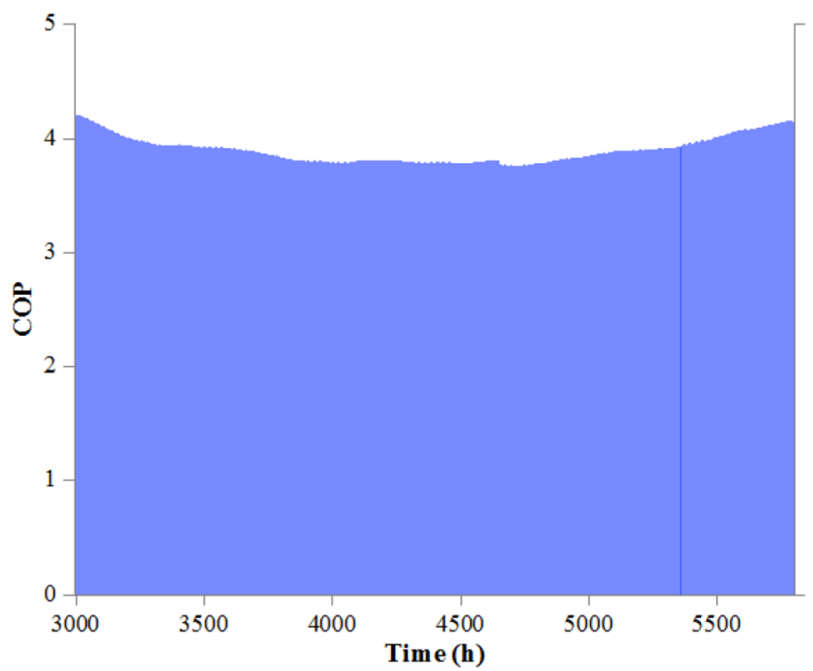

(a)

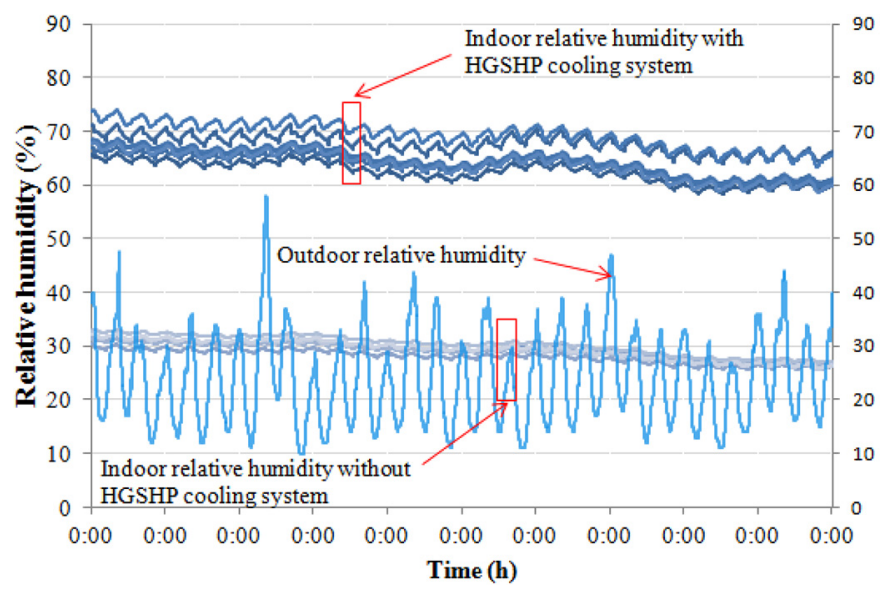

Fig. 19. Comparison between indoor and outdoor relative humidity in a typical days (July 1 until July 30) for $\mathrm{L}_{\mathrm{GHX}}=500 \mathrm{~m}$, $\mathrm{D}_{\mathrm{i}-\mathrm{GHX}}=0.0363 \mathrm{~m}$ and $\mathrm{Z}=1 \mathrm{~m}$.

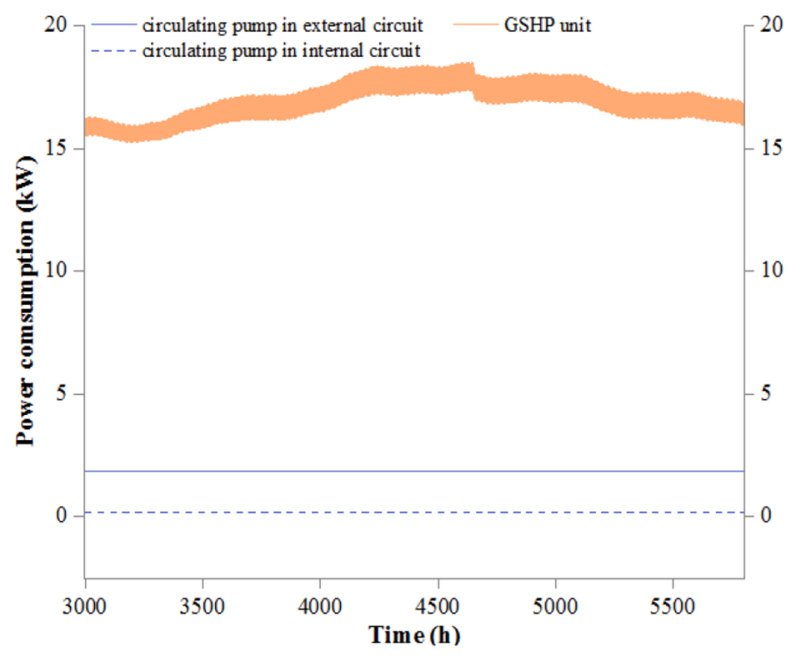

(b)

Fig. 20. The power analysis of the first year HGSHPs operation, (a) the power consumption distribution, (b) the COP distribution for $\mathrm{L}_{\mathrm{GHX}}=500 \mathrm{~W} / \mathrm{m}, \mathrm{D}_{\mathrm{i}-\mathrm{GHX}}=0.0363 \mathrm{~m}, \mathrm{~m}_{\mathrm{w}-\mathrm{GHX}}=1 \mathrm{~kg} / \mathrm{s}$ and $\mathrm{Z}=1 \mathrm{~m}$.

Based on the results obtained in this study, it could be concluded that the development of the GSHP system is promising and profitable solution for providing building sector with energy-efficient cooling in the hot Saharan climates and arid areas, and we recommend by taking into account all the optimized design criteria which could provide some reference on HGSHPs utilization in like these hot-dry regions.

\section{Nomenclature}

$T_{\text {in-con }} \quad$ Condenser entering water temperature $\left({ }^{\circ} \mathrm{C}\right)$

$T_{\text {out }- \text { con }} \quad$ Condenser leaving water temperature $\left({ }^{\circ} \mathrm{C}\right)$

$\dot{m}_{w-C o n} \quad$ Condenser water mass flow rate $(\mathrm{kg} / \mathrm{s})$

COP Coefficient of performance in cooling mode
$\dot{m}_{w-E v p}$

$T_{\text {in-Evp }}$

$T_{\text {out }-E v p}$

$T_{\text {in-GHX }}$

$T_{\text {out }-G H X}$

$\dot{m}_{w-G H X}$

$\mathrm{W}$

$T_{i n-R F}$

$T_{\text {out }-R F}$

$\dot{m}_{w-R F}$

$T_{s}$

$Q_{b}$

$Q_{g}$

$Q_{E v p}$

$Q_{C o n}$

$\mathrm{C}_{p-\mathrm{H}_{2} \mathrm{O}}$
Evaporator water mass flow rate $(\mathrm{kg} / \mathrm{s})$

Evaporator entering water temperature $\left({ }^{\circ} \mathrm{C}\right)$

Evaporator leaving water temperature $\left({ }^{\circ} \mathrm{C}\right)$

GHX entering water temperature $\left({ }^{\circ} \mathrm{C}\right)$

GHX leaving water temperature $\left({ }^{\circ} \mathrm{C}\right)$

GHX water mass flow rate $(\mathrm{kg} / \mathrm{s})$

Power consumption $(\mathrm{kW})$

$\mathrm{RF}$ entering water temperature $\left({ }^{\circ} \mathrm{C}\right)$

$\mathrm{RF}$ Leaving water temperature $\left({ }^{\circ} \mathrm{C}\right)$

$\mathrm{RF}$ water mass flow rate $(\mathrm{kg} / \mathrm{s})$

Soil temperature $\left({ }^{\circ} \mathrm{C}\right)$

The heat absorbed from the building (W)

The heat transferred to the ground (W)

The heat absorbed from the evaporator (W)

The heat transfer rate from condenser (W)

The fluid specific heat of the fluid $(\mathrm{kJ} / \mathrm{kgK})$ 


$\begin{array}{ll}\mathrm{E} & \text { The annual power consumption } \mathrm{kWh} / \mathrm{y} \\ C_{\text {inv }} & \text { The investment cost of GSHPs }(\$ / \mathrm{y}) \\ C_{\text {elec }} & \text { The annual cost of power consumption }(\$ / \mathrm{y}) \\ C_{\text {heatpump }} & \text { The cost of heat pump }(\$) \\ C_{\text {pump }} & \text { The cost of circulation pump }(\$) \\ c_{\text {earthworks }} & \text { The regional price of the drilling and refilling } \\ & \left(\$ / \mathrm{m}^{2}\right) \\ c_{\text {Pipe }} & \text { The regional cost of polyethylene pipe per } \\ & \text { meter }(\$ / \mathrm{m}) \\ i & \text { The interest rate }(\%) \\ n & \text { The number of operation years }(\mathrm{y}) \\ H_{\text {pump }} & \text { The pressure drop }(\text { Pa) } \\ E_{t a r i f f} & \text { The tariff of unit electricity consumption } \\ & \text { (\$/kWh) } \\ L_{G H X} & \text { The pipe length of heat exchanger }(\mathrm{m}) \\ \mathrm{NPT} & \text { The number of parallel pipe } \\ \mathrm{Z} & \text { The depth of the ground (m) } \\ \dot{T}_{s} & \text { The mean value of the ground surface temper- } \\ & \text { ature }\left({ }^{\circ} \mathrm{C}\right) \\ A_{s} & \text { The amplitude of surface temperature } \\ \text { TAC } & \text { Total annual cost }(\$ / \mathrm{y})\end{array}$

Subscripts

$\begin{array}{ll}\text { b } & \text { Building } \\ \mathrm{C} & \text { Cooling mode } \\ \text { Con } & \text { Condenser } \\ \text { Comp } & \text { Compressor } \\ \text { Pump } & \text { Circulating pump } \\ \text { elec } & \text { Electricity } \\ \text { evp } & \text { Evaporator } \\ \text { g } & \text { Ground } \\ \text { i } & \text { Inner } \\ \text { RF } & \text { Radiant floor } \\ \text { Min } & \text { Minimum } \\ \text { Max } & \text { Maximum } \\ \text { s } & \text { System } \\ \text { W } & \text { Water }\end{array}$

Abbreviation

$\begin{array}{ll}\text { EER } & \text { Energy efficiency ratio } \\ \text { GSHP } & \text { Ground source heat pump } \\ \text { GHX } & \text { Ground heat exchangers } \\ \text { GHP } & \text { Ground heat pump } \\ \text { HDPE } & \text { High-density polyethylene } \\ \text { HGSHP } & \text { Horizontal ground source heat pump } \\ \text { OF } & \text { Objective function } \\ \text { RF } & \text { Radiant floor } \\ \text { SEER } & \text { Seasonal energy efficiency ratio }\end{array}$

Greek letters

$$
\alpha_{g} \quad \text { Ground diffusivity }\left(\mathrm{m}^{2} / \text { day }\right)
$$

This research was partly supported by the basic research project by the "Laboratoire des Procédés Thermiques (LPT)", "Centre de Recherches et des Technologies de l'Energie (CRTEn)", Tunisia.
And by the laboratory of new and renewable energy in arid and saharan zones - LENREZA, Algeria.

\section{References}

1. N. Giti, N. Younes, Y. Hossein, Designing and optimization of solar assisted ground source heat pump system to supply heating, cooling and hot water demands, Geothermics 82, 212-231 (2019)

2. R. Ghedamsi, N. Settou, A. Gouareh, A. Khamouli, N. Saifi, B. Recioui, B. Dokkar, Modeling and forecasting energy consumption for residential buildings in Algeria using bottom-up approach, Energy Build. 121, 309-317 (2016)

3. F. Amri, The relationship amongst energy consumption (renewable and non-renewable), and GDP in Algeria, Renew. Sustain. Energy Rev. 76, 62-71 (2017)

4. S. Sanaye, B. Niroomand, Thermal-economic modeling and optimization of vertical ground-coupled heat pump, Energy Convers. Manag. 50, 1136-1147 (2009)

5. J. Luo, W. Xue, T. Hu, W. Xiang, J. Rohn, Thermo-economic analysis of borehole heat exchangers (BHE) grouted using drilling cuttings in a dolomite area, Appl. Therm. Eng. 150, 305-315 (2019)

6. Y. Zhao, Z. Shigang, L. Xun, Cost-effective optimal design of groundwater source heat pumps, Appl. Therm. Eng. 23, 1595-1603 (2003)

7. S. Sanaye, B. Niroomand, Horizontal ground coupled heat pump: thermal-economic modeling and optimization, Energy Convers. Manag. 51, 2600-2612 (2010)

8. N. Kayaci, H. Demir, Long time performance analysis of ground source heat pump for space heating and cooling applications based on thermo-economic optimization criteria, Energy Build. 163, 121-139 (2018)

9. M. Inalli, H. Esen, Experimental thermal performance evaluation of a horizontal ground-source heat pump system, Appl. Therm. Eng. 24, 2219-2232 (2004)

10. M.J. Kim, S.R. Lee, S. Yoon, J.S. Jeon, An applicable design method for horizontal spiral-coil-type ground heat exchangers, Geothermics 72, 338-347 (2018)

11. M. De Rosa, F. Ruiz-Calvo, J.M. Corberán, C. Montagud, L. A. Tagliafico, A novel TRNSYS type for short-term borehole heat exchanger simulation: B2G model, Energy Convers. Manag. 100, 347-357 (2015)

12. C. Lyu, W.H. Leong, M. Zheng, G. Chen, S. Ye, Y. Liu, Verification and analysis of a dynamic simulation model of ground-coupled heat pump with solar seasonal heat storage system, Procedia Eng. 205, 3154-3161 (2017)

13. Y. Noorollahi, H.G. Arjenaki, R. Ghasempour, Thermoeconomic modeling and GIS-based spatial data analysis of ground source heat pump systems for regional shallow geothermal mapping. Renew. Sustain. Energy Rev. 72, 648-660 (2017)

14. G. Radioti, K. Sartor, R. Charlier, P. Dewallef, F. Nguyen, Effect of undisturbed ground temperature on the design of closed-loop geothermal systems: a case study in a semi-urban environment, Appl. Energy 200, 89-105 (2017)

15. H. Saibi, Geothermal resources in Algeria, Renew. Sustain. Energy Rev. 13, 2544-2552 (2009)

16. A. Abdelali, I.E. Nezli, A.S. Benhamida, Geothermometry application to the Continental Intercalaire geothermal aquifer: a case study of Ouargla region, Energy Procedia 119, 264-269 (2017) 
17. The national society of electricity and gas in Algeria. Sonelgaz of the East

18. N. Kayaci, H. Demir, Comparative performance analysis of building foundation Ground heat exchanger, Geothermics 83, $101710(2020)$

19. Webpage: http://www.algerie.prix-construction.info (accessed June 2019)

20. A. Cacabelos, P. Eguía, J.L. Míguez, E. Granada, M.E. Arce, Calibrated simulation of a public library HVAC system with a ground-source heat pump and a radiant floor using TRNSYS and GenOpt, Energy Build. 108, 114-126 (2015)

21. M.H. Benzaama, S. Menhoudj, C. Maalouf, A. Mokhtari, M. Lachi, Experimental and numerical analysis of the energy performance of a water/soil exchanger coupled to a cooling floor for North Africa, Geothermics 80, 8-19 (2019)
22. N. Nabiha, H. Majdi, K. Sami, F. Abdelhamid, Energy and exergy analysis of horizontal ground heat exchanger for hot climatic condition of northern Tunisia, Geothermics 53, 270-280 (2015)

23. N. Naili, M. Hazami, I. Attar, A. Farhat, In-field performance analysis of ground source cooling system with horizontal ground heat exchanger in Tunisia, Energy 61, 319-331 (2013)

24. N. Naili, M. Hazami, I. Attar, A. Farhat, Assessment of surface geothermal energy for air conditioning in northern Tunisia: direct test and deployment of ground source heat pump system, Energy Build. 111, 207-217 (2016)

25. S. Kavanaugh, K. Rafferty, Geothermal heating and cooling: design of ground source heat pump systems (ASHRAE, Atlanda, 2014)

Cite this article as: Sabrin Korichi, Bachir Bouchekima, Nabiha Naili, Messaouda Azzouzi, Performance analysis of horizontal ground source heat pump for building cooling in arid Saharan climate: thermal-economic modeling and optimization on TRNSYS, Renew. Energy Environ. Sustain. 6, 1 (2021) 